\title{
Rhodoliths in Brazil: Current knowledge and potential impacts of climate change
}

\author{
Paulo Antunes Horta ${ }^{*}$, Pablo Riul', Gilberto M. Amado Filho ${ }^{3}$, Carlos Frederico D. Gurgel', \\ Flávio Berchez ${ }^{4}$, José Marcos de Castro Nunes ${ }^{5}$, Fernando Scherner ${ }^{6}$, Sonia Pereira ${ }^{6}$, Tito Lotufo ${ }^{7}$, \\ Letícia Peres $^{l}$, Marina Sissini ${ }^{1}$, Eduardo de Oliveira Bastos ${ }^{l}$, João Rosa ${ }^{1}$, Pamela Munoz ${ }^{l}$, Cintia \\ Martins $^{l}$, Lidiane Gouvêa ${ }^{l}$, Vanessa Carvalho ${ }^{l}$, Ellie Bergstrom ${ }^{l}$, Nadine Schubert ${ }^{8}$, Ricardo G. \\ Bahia $^{3}$, Ana Claudia Rodrigues ${ }^{1}$, Leonardo Rörig ${ }^{I}$, José Bonomi Barufi ${ }^{1}$, Marcia Figueiredo ${ }^{3}$
}

\author{
${ }^{1}$ Departamento de Botânica, Centro de Ciências Biológicas Universidade Federal de Santa Catarina \\ (CEP:88040-970, Florianópolis, SC, Brasil) \\ ${ }^{2}$ Departamento de Engenharia e Meio Ambiente, Universidade Federal da Paraíba \\ (CEP: 58297-000, Rio Tinto, PB, Brasil) \\ ${ }^{3}$ Instituto de Pesquisas Jardim Botânico do Rio de Janeiro \\ (CEP: 22460-030, Rio de Janeiro, RJ, Brasil) \\ ${ }^{4}$ Laboratório de Algas Marinhas, Instituto de Biociências, Universidade de São Paulo \\ (CEP: 05508-090, São Paulo, SP, Brasil) \\ ${ }^{5}$ Laboratório de Algas Marinhas, Instituto de Biologia, Universidade Federal da Bahia \\ (CEP: 40210-730, Salvador, BA, Brasil) \\ ${ }^{6}$ Laboratório de Ficologia, Departamento de Biologia, Universidade Federal Rural de Pernambuco \\ (CEP: 52171-900, Recife, PE, Brasil) \\ ${ }^{7}$ Instituto de Oceanografia, Universidade de São Paulo \\ (CEP: 05508-090, São Paulo, SP, Brasil) \\ ${ }^{8}$ Programa de Pós-Graduação em Oceanografia, Departamento de Geociências, Universidade Federal de Santa Catarina(UFSC) \\ (CEP: 88040-900, Florianópolis, SC, Brasil)
}

*Corresponding author: pahorta@hotmail.com.br

Financial Support: CNPQ, CAPES, FAPESP.

\begin{abstract}
Rhodolith beds are important marine benthic ecosystems, representing oases of high biodiversity among sedimentary seabed environments. They are found frequently and abundantly, acting as major carbonate 'factories' and playing a key role in the biogeochemical cycling of carbonates in the South Atlantic. Rhodoliths are under threat due to global change (mainly related to ocean acidification and global warming) and local stressors, such as fishing and coastal run-off. Here, we review different aspects of the biology of these organisms, highlighting the predicted effects of global change, considering the additional impact of local stressors. Ocean acidification (OA) represents a particular threat that can reduce calcification or even promote the decalcification of these bioengineers, thus increasing the ecophysiological imbalance between calcareous and fleshy algae. OA should be considered, but this together with extreme events such as heat waves and storms, as main stressors of these ecosystems at the present time, will worsen in the future, especially if possible interactions with local stressors like coastal pollution are taken into consideration. Thus, in Brazil there is a serious need for starting monitoring programs and promote innovative experimental infrastructure in order to improve our knowledge of these rich environments, optimize management efforts and enhance the needed conservation initiatives.
\end{abstract}

Descriptors: Algae, Conservation, Brazil, Global warming, Pollution, Ocean acidification.

\section{RESUMO}

Bancos de rodolitos formam oásis de alta biodiversidade em ambientes marinhos de fundo arenoso. Os rodolitos são formados por espécies bioconstrutoras, que fornecem abrigo e substrato para diversas e abundantes comunidades bentônicas. No Brasil esses ambientes são frequentes, representando grandes "fábricas" de carbonato com um papel fundamental no ciclo biogeoquímico do carbono no Atlântico Sul. Estes organismos e ambientes estão ameaçados pelas mudanças climáticas (principalmente a acidificação dos oceanos e o aquecimento global) e pelos estressores locais, tais como os impactos causados pela pesca e as descargas costeiras de efluentes. Neste trabalho fazemos uma revisão da taxonomia, filogenia e biologia desses organismos, com destaque para os efeitos previstos das mudanças climáticas e suas relações com estressores locais. A maioria dos estudos acerca dos efeitos das mudanças climáticas e da acidificação dos oceanos em algas calcárias relatam respostas negativas não só no crescimento e na calcificação, mas também no processo de fotossíntese, espessura da parede celular, reprodução e sobrevivência das algas. Este cenário reforça a necessidade em estabelecer uma consistente rede de trabalho para proporcionar um programa de monitoramento amplo e de longo prazo, bem como infraestrutura para avaliações experimentais de impactos locais e regionais das mudanças climáticas e dos estressores locais em bancos de rodolitos.

Descritores: Algas, Conservação, Brasil, Mudanças climáticas, Poluição, Acidificação dos oceanos

http://dx.doi.org/10.1590/S1679-875920160870064sp2 


\section{INTRODUCTION}

Pink or red "rocks" on the sea floor often consist of different morphotypes of a particular kind of calcareous red algae (Corallinophycidae). This particular kind of seaweed, known as coralline red algae, present calcium carbonate impregnated (i.e. calcified) cell walls. Crustose coralline red algae are completely calcified encrusting organisms (Figure 1) that either adhere tightly to hard substratum or remain unattached to the seafloor (BROOM et al., 2008). Rhodoliths (including maërl) can be defined as calcareous nodules composed of more than $50 \%$ of coralline red algal material and consisting of one to several coralline species growing together (BOSELLINI; GINSBURG, 1971). They may cover extensive areas of the seafloor forming large beds, often associated with high marine biodiversity (STELLER et al., 2003; RIUL et al., 2009; PEÑA et al., 2014). Rhodoliths may be composed entirely of encrusting coralline algae or may have a core of noncoralline material (e.g. a shell, piece of dead coral or a pebble), in addition to encrustations by other calcified organisms. They are distributed worldwide (FOSTER, 2001), from tropical to polar regions (ADEY; STENECK, 2001), and from the intertidal zone to depths of $268 \mathrm{~m}$ (LITTLER et al., 1986). Rhodolith beds represent one of the largest carbonate depositional environments in the world (TESTA; BOSENCE, 1999), which makes them an important component in the global carbon biogeochemical cycle and hence, in the atmospheric $\mathrm{CO}_{2}$ balance (OLIVEIRA, 1996).

In Brazil, rhodolith beds extend over almost the entire continental shelf from Maranhão ( $\left.0^{\circ} 50^{\prime} \mathrm{S}\right)$ to Santa Catarina state $\left(27^{\circ} 17^{\prime} \mathrm{S}\right)$. They predominate within the mesophotic zone ( $\sim 30-150 \mathrm{~m}$ depth) along the continental shelf, on the tops of seamounts, and around oceanic islands (AMADO-FILHO; PEREIRA-FILHO, 2012). The mesophotic coralline ecosystems represent extensions of shallower ecosystems (HINDERSTEIN et al., 2010), however, information on biotic and abiotic aspects of mesophotic habitats remains extremely scarce, due to logistic and technological restrictions, when compared to shallow habitats (BRIDGE et al., 2011). However, recent advances in mixed-gas diving techniques, complemented by ROV observations, and high-resolution multi-beam bathymetric mapping systems allow us to begin determining rhodolith beds' extent, structure, and dynamics (FOSTER et al., 2013).
Rhodoliths represent heavily calcified organisms, depositing calcium carbonate in the form of high $\mathrm{Mg}$ calcite, a mineral that attains up to $\sim 90 \%$ of the dry weight of these species (WOELKERLING, 1993; OLIVEIRA, 1997) and ensures good preservation in fossil record. These features call the attention not only of phycologists, but also palaeontologists and geologists interested in the carbonate abundance of limestone deposits found since the Cretaceous (LITTLER, 1972; BASSO, 2012). It has been estimated that the Brazilian continental shelf carbonate stock holds $2 \times 10^{11}$ tonnes of $\mathrm{CaCO}_{3}$ (MILLIMANN; AMARAL, 1974). Among the rhodolith beds along the Brazilian coast, the Abrolhos shelf boasts the world's largest expansion of rhodoliths in the Atlantic, with a mean relative cover of rhodoliths around $69.1 \%( \pm 1.7 \%)$ and a mean density of $211 \pm 20$ nodules per square meter (AMADO-FILHO et al., 2012a). These authors estimated a mean $\mathrm{CaCO}_{3}$ production rate of about $0.025 \mathrm{Gt} /$ year for the Abrolhos shelf, containing approximately $5 \%$ of the $\mathrm{CaCO}_{3}$ inventory of all the world's carbonate banks. In addition to its importance in the global carbon cycle (VAN DER HEIJDEN; KAMENOS, 2015), the reported amount of limestone has also called the attention of multinational companies interested in the large-scale exploitation of these deposits for agronomic purposes. However, the relatively low growth rate of mesophotic rhodoliths (about $1.0 \mathrm{~mm}$ per year, BLAKE; MAGGS, 2003; AMADO- FILHO et al., 2012a) confers on this resource a nearly non-renewable characteristic, at least on human time-scales (WILSON et al., 2004). In addition to the use of rhodolith beds as a source of $\mathrm{CaCO}_{3}$, other potential economic uses include exploiting their associated biodiversity as a source of bioactive compounds in the pharmacology, agriculture and nutraceutical industries (AMADO-FILHO; PEREIRAFILHO, 2012; MARINS et al., 2012).

Despite their great importance for biodiversity resilience and the global carbon budget, in Brazil the functional ecology of these complex habitats, considering the intrinsic latitudinal and vertical variability, has received relatively little attention. In contrast, research programs and initiatives in Europe (e.g. BIOMAERL, 1996-1999; United Nations Environment Programme, UNEP, 2007, 2015) have contributed to the knowledge of: (1) rhodolith bed diversity, (2) rhodolith-bed associated biota, (3) functional roles played by key elements of the biota, and (4) impacts of anthropogenic stressors. This information is being used to establish research and conservation priorities for European rhodolith-dominated communities, and to suggest how these may be achieved. 

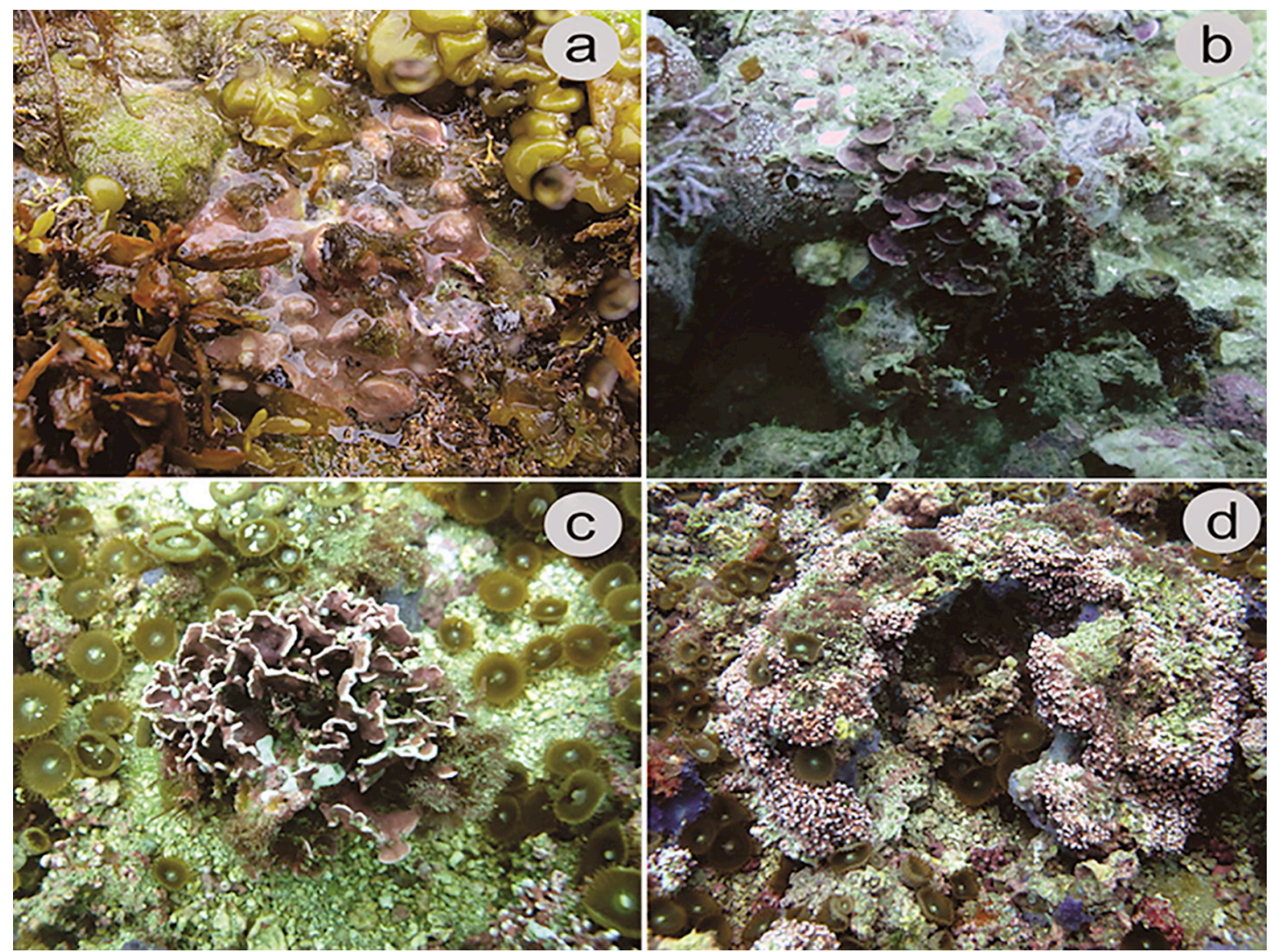

Figure 1. Diversity of coralline red algal forms. (a) Encrusting form in the intertidal zone; (b) prostrate foliose form; (c) erect foliose rhodolith; (d) fruticose rhodolith. Photos: M.N. Sissini.

In Brazil, only in the last decade have rhodolith beds started gaining more prominence with an increase in the number of published studies on community structure, habitat mapping, the influence of anthropogenic impacts, and molecular systematics (see Table 1).

In the light of the great ecological and economic importance of rhodoliths, the range of threats they face currently, as well as those they will face in the future, and the lack of knowledge on the extent of their distribution and diversity in Brazil, the present bibliographical review aims to provide the basic information necessary to guide future studies, particularly those related to global climate change and its interaction with local stressors.

\section{ECOLOGICAL ROLE}

Rhodolith beds provide significant changes in the physiognomy of benthic communities, compared to those in the surrounding sandy bottom environments (Figure 2; FOSTER et al., 2013). The rhodolith-bed forming species are considered ecosystem engineers (HALFAR; RIEGL, 2013) and their growth and accumulation over geological time have constituted important sedimentary deposits (DIAS, 2000). They can also be considered key species because their thallus shape and skeletal stability promote structural changes in the environment, increasing habitat heterogeneity and niche availability, resulting in increased species diversity (STELLER et al., 2003; FOSTER et al., 2013). In general, higher species diversity is attributed to the greater availability of refuges and other resources that reduce losses derived from competitive exclusion, predation, and physical disturbance events. For these reasons rhodolith beds have been proposed as one of the most valuable habitats for studies on marine biodiversity both in Europe (BARBERA et al., 2003) and in Brazil (HORTA et al., 2001).

\section{TAXONOMY AND MORPHOLOGY}

Rhodoliths comprise the third most diverse group within the Rhodophyta, with approximately 600 recognized 
Table 1. Summary of published studies on Brazilian rhodolith beds.

\begin{tabular}{|c|c|}
\hline Main focus & References \\
\hline \multirow{4}{*}{ Meso- and small-scale distribution } & AMADO-FILHO et al. $(2007,2012 a)$ \\
\hline & RIUL et al. (2009) \\
\hline & PEREIRA-FILHO et al. $(2011,2012)$ \\
\hline & MOURA et al. (2013) \\
\hline \multirow{6}{*}{ Rhodolith bed structure } & TESTA; BOSENCE (1999) \\
\hline & GHERARDI (2004) \\
\hline & AMADO-FILHO et al. (2007) \\
\hline & RIUL et al. (2009) \\
\hline & BAHIA et al. (2010) \\
\hline & PASCELLI et al. (2013) \\
\hline \multirow{5}{*}{ Contribution to global carbonate production } & BRASILEIRO et al. (2015) \\
\hline & KEMPF (1970) \\
\hline & MILLIMAN; AMARAL (1974) \\
\hline & MELLO et al. (1975) \\
\hline & AMADO-FILHO et al. (2012a) \\
\hline \multirow{15}{*}{ Species composition of rhodolith beds } & TESTA (1997) \\
\hline & HORTA (2002) \\
\hline & AMADO-FILHO et al. (2007) \\
\hline & NUNES et al. (2008) \\
\hline & FARIAS (2010) \\
\hline & VILLAS-BÔAS et al. $(2009,2014 a)$ \\
\hline & BAHIA et al. $(2010,2014)$ \\
\hline & FIGUEIREDO et al. (2012) \\
\hline & CRESPO et al. (2014) \\
\hline & TORRANO-SILVA et al. (2014) \\
\hline & HENRIQUES et al. (2014 a and b) \\
\hline & VIEIRA-PINTO et al. (2014) \\
\hline & COSTA et al. (2014) \\
\hline & BORGES et al. (2014) \\
\hline & SISSINI et al. (2014) \\
\hline \multirow{17}{*}{ Associated communities/organisms } & BAHIA et al. (2015) \\
\hline & TAMEGA et al. (2015) \\
\hline & FIGUEIREDO et al. (1997) \\
\hline & GHERARDI \& BOSENCE (2001) \\
\hline & ROCHA et al. (2005) \\
\hline & FIGUEIREDO et al. (2007) \\
\hline & METRI \& ROCHA (2008) \\
\hline & AMADO-FILHO et al. (2010) \\
\hline & SCHERNER et al. (2010) \\
\hline & PEREIRA-FILHO et al. (2011) \\
\hline & SANTOS et al. (2011) \\
\hline & AMADO-FILHO \& PEREIRA-FILHO (2012) \\
\hline & BERLANDI et al. (2012) \\
\hline & PASCELLI et al. (2013) \\
\hline & GONDIM et al. (2014) \\
\hline & VILLAS-BÔAS et al. (2014a) \\
\hline & PEREIRA-FILHO et al. (2015) \\
\hline \multirow{5}{*}{ Influence of environmental factors on rhodolith bed habitats } & MEIRELLES et al. (2015) \\
\hline & RIUL et al. (2008) \\
\hline & MARINS et al. (2012) \\
\hline & VILLAS-BÔAS et al. (2014b) \\
\hline & FIGUEIREDO et al. (2015) \\
\hline
\end{tabular}




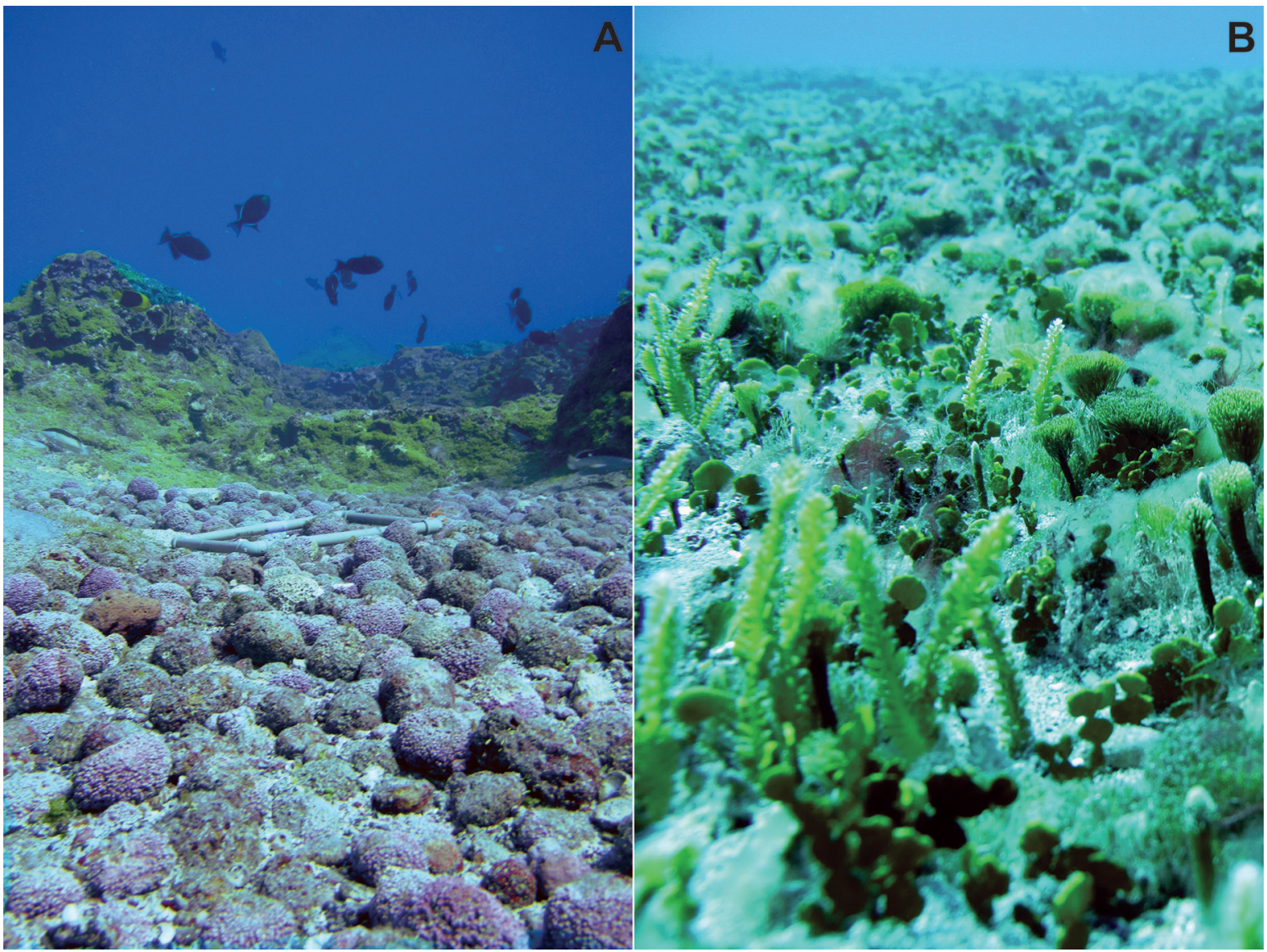

Figure 2. Different rhodolith physiognomies are sometimes observed at a single site, such as on Trindade Island. (A) Rhodolith beds without abundant associated benthic flora and (B) rhodolith beds with abundant overgrowth of other algal species. Photos: M.N. Sissini.

morpho-species (BRODIE; ZUCCARELLO, 2007; GUIRY; GUIRY, 2015). To date, 48 species of encrusting coralline red algae have been recognized in the Brazilian flora: 9 Sporolithaceae, 25 Corallinaceae, and 14 Hapalidiaceae (Table 2). Of those, about 26 species are known, on the Brazilian coast, as rhodolith-forming. In relation to habitat or morphotype, there are no studies distinguishing between the occurrence of exclusively rhodolith-forming or exclusively non-rhodolith-forming species.

Because rhodolith beds consist of a diversity of living organisms, they are characterized as being both temporally and spatially dynamic ecosystems (AMADO FILHO et al., 2010; BARRETO, 1999; DIAS, 2001; DIAS; VILLAÇA, 2012). The surface morphology of rhodoliths presents variations regulated by depth (ADEY et al., 1982), hydrodynamic bioerosive processes and taxonomy (BOSENCE, 1983). Depth is also a regulatory factor for rhodolith density $\left(\mathrm{m}^{-2}\right)$ and size (Figure 3; BAHIA et al., 2010; PASCELLI et al., 2013). A comparison of three areas of the Brazilian tropical continental shelf with contrasting slopes showed that in areas with a gentle slope, rhodoliths increased in size and decreased in abundance $\left(\mathrm{m}^{-2}\right)$, with a gentle increase of the ellipsoidal to spherical shape with depth (BAHIA et al., 2010). In contrast, rhodoliths from narrow shelves and steep slopes decreased in size but increased in abundance.

Studies have also noted that the number and size of protuberances, hollows or cavities that characterize different morphotypes of rhodoliths are fundamental features that determine the diversity and abundance of the associated flora and fauna (e.g., AMADO-FILHO et al., 2010; BERLANDI et al., 2012). All this morphological plasticity makes the taxonomical evaluation of their diversity difficult, particularly at the species level.

\section{ASSOCIATED FAUNA AND FLORA}

In some large areas of the Brazilian coast, the lack of hard substrate prevents the occurrence of most macroalgal species. In these areas rhodolith beds provide habitats for fleshy macroalgae and other groups of benthic organisms, 
Table 2. Species of Corallinophycidae (excluding articulate forms) reported for the Brazilian coast. (* indicates the species that still need to be revised using modern techniques and nomenclature; $\circ$ indicates the species that have been added in the last three years; \# indicates rhodolith-forming species).

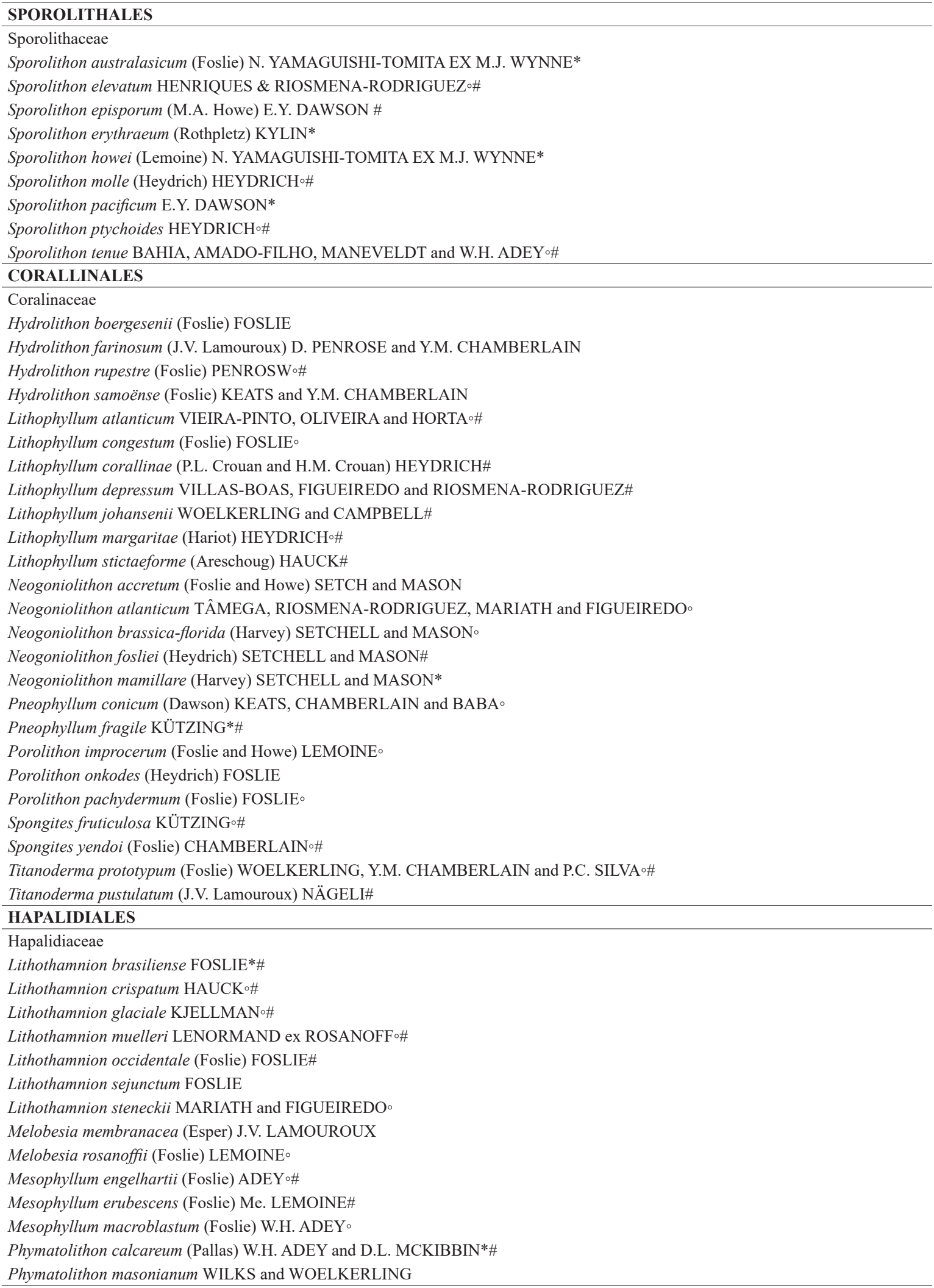





Figure 3. Vertical and latitudinal changes observed in the size (volume) and density of rhodoliths from different beds on the Brazilian coastline (based on BAHIA et al., 2010 and PASCELLI et al., 2013). PB: Paraíba; BA: Bahia; ES: Espírito Santo; SC: Santa Catarina.

thus increasing local biodiversity (RIUL et al., 2009) and primary production. Biodiversity, productivity and live biomass (standing stock) in shallow rhodolith beds are higher than in most of their equivalents found in deeper areas or in unconsolidated flat bottom communities (RIUL et al., 2009). Remarkably, rhodolith beds provide refuge for small animals, as abundant mesograzers in southern Brazil (SCHERNER et al., 2010), and many larger species of fish and invertebrates that occur on adjacent reef systems will pass over these beds, looking for food and substrate for reproduction. Despite such limitations in supporting a "complete" reef assemblage, rhodolith beds likely represent migration corridors for several species when they cover large inter-reef areas, such as those found in the Abrolhos Bank (AMADO-FILHO et al., 2012a). When compared to deep-water sand and mud-benthic communities, rhodolith beds represent submerged oases (Figure 4). In this context, PEREIRA-FILHO et al. (2015) hypothesized that the coalescence of rhodoliths constitutes an early successional stage in the formation of large coralline reefs on southwestern Atlantic tropical shelves.

In a study evaluating the marine biota of the Brazilian Exclusive Economic Zone, LAVRADO (2006) reported a Shannon-Wiener diversity index of 4.0 and 5.1 for specific areas down to $250 \mathrm{~m}$ depth and associated this increase in the diversity of epibenthic communities to the presence of rhodolith beds. Information about density, dimension, shape and percentage of the live surface of rhodoliths, associated fauna and flora, rhodolith growth rates, and calcium carbonate mineralization for specific areas of the Brazilian Economic Exclusive Zone.

PEREIRA-FILHO et al. (2012) and AMADOFILHO et al. (2012b) showed that the mesophotic zone of seamount tops and insular shelves of oceanic islands present rich benthic communities dominated by rhodoliths. Despite their extensive area, the fauna and flora richness associated with rhodolith beds in Brazil is very poorly studied and research has focused on few specific sites and taxa (Figure 5). However, the importance of rhodolith beds in supporting a high diversity and abundance of marine species in comparison with surrounding habitats is recognized (NELSON, 2009), and at least one endemic species, the polychaete Sabellaria corallinea, is known to occur only in the rhodolith beds of northeastern Brazil (SANTOS et al., 2011).

In the few studies that have evaluated the fauna associated with rhodolith beds, 136 solitary and 32 colonial species of invertebrates, totalling 168 taxa, have been reported growing in $100 \mathrm{~m}^{2}$ of a subtropical rhodolith bed located on Arvoredo Island, southern Brazil (METRI; ROCHA, 2008). Among the solitary forms, Polychaeta, Crustacea and Mollusca were the most important groups, while among the colonial forms the Porifera Pachataxa sp. and the Ascidiacea Didemnum sp. were registered in $90 \%$ of the samples. Another study by BERLANDI et al. (2012) compared the Polychaeta composition of different 


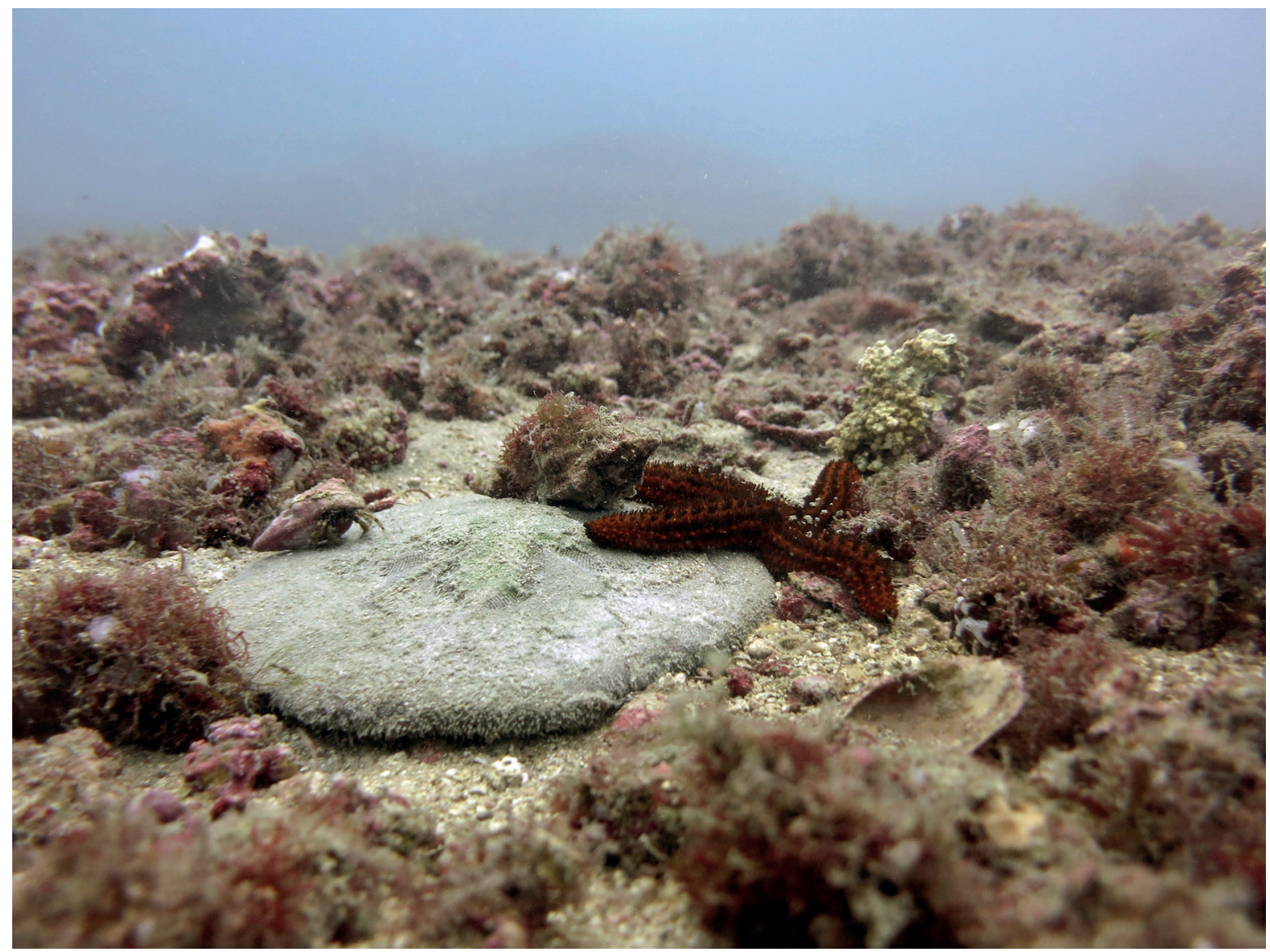

Figure 4. Example of the seaweed and zoobenthic communities found in rhodolith beds on the Brazilian coast. This picture highlights the presence of gastropods, echinoderms and a turf algae assemblage on Desert Island, southern Brazil. Photo: P.A. Horta.

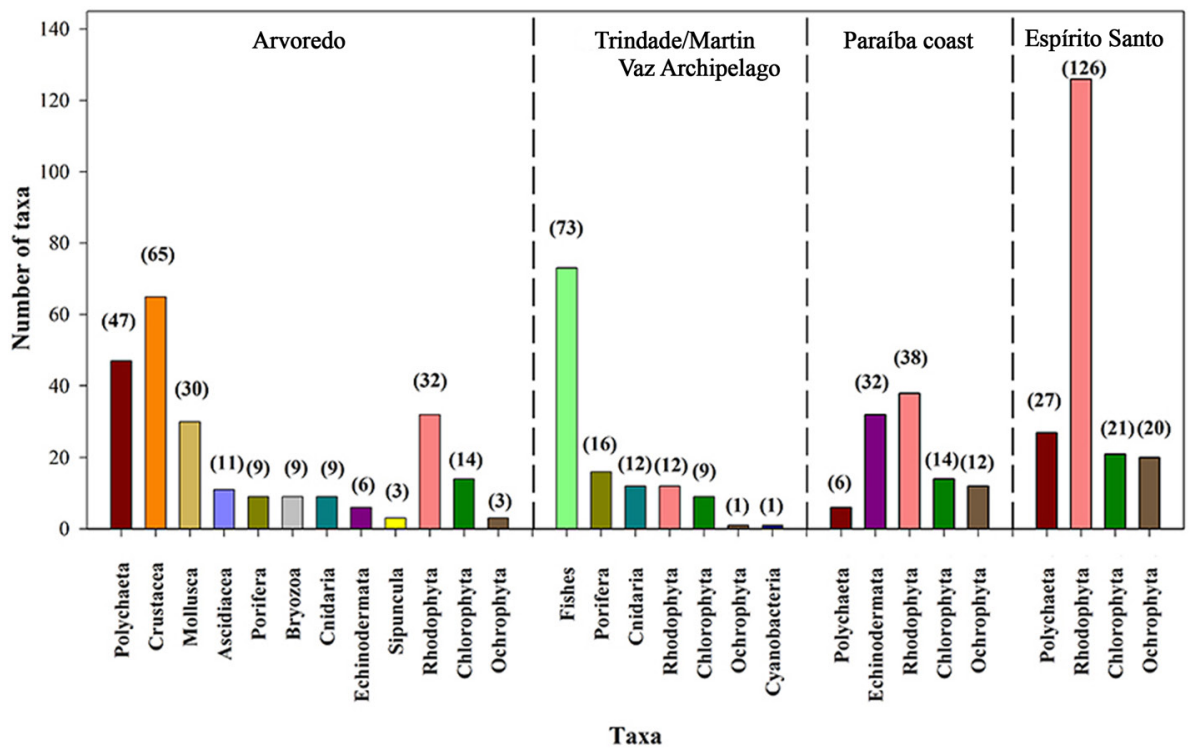

Figure 5. Fauna and flora associated with Brazilian rhodolith beds. Arvoredo Island, according to BOUZON \& FREIRE (2007), MERTI \& ROCHA (2008), SCHERNER et al. (2010) and PASCELLI et al. (2013), Trindade and Martin Vaz Island according to PEREIRO-FILHO et al. (2011), rhodolith beds off the coast of Paraíba according to RIUL et al. (2009), SANTOS et al. (2011) and GONDIM et al. (2014), and Espírito Santo according to FIGUEIREDO et al. (2007), AMADO-FILHO et al. (2010) and BERLANDI et al. (2012). Numbers indicate the number of species described for the taxa and the same color was used for the same taxa at each site. 
rhodolith forms (small rhodoliths with long branches and large rhodoliths with short branches) and found that of the 26 families that had been found, 4 were exclusively associated with large rhodoliths and 9 exclusively with the small ones. The rhodolith-bed associated fauna and flora have been studied almost exclusively in beds found above $30 \mathrm{~m}$.

In relation to the rhodolith-bed associated flora, some studies have indicated a high and specific diversity. For example, AMADO-FILHO et al. (2010) reported that in the southern part of Espírito Santo state rhodolith beds provide an important habitat for epibenthic communities, supporting 25\% of the known macroalgal species richness along the Brazilian coast. Also, new records of seaweeds have been found specifically associated with the rhodolith beds of Espírito Santo and the northeastern and southeastern Brazilian coasts (AMADO-FILHO et al., 2010, GUIMARÃES; AMADOFILHO, 2008; RIUL et al., 2009).

\section{GLOBAL AND LOCAL THREATS}

Rhodolith beds, like many other marine ecosystems, are affected by ongoing global change due to the rise in the concentration of greenhouse gases in the atmosphere $\left(\mathrm{CO}_{2}\right.$ in particular) and all its associated consequences, such as an increase in seawater temperatures $\left(1-4^{\circ} \mathrm{C}\right.$ by 2100$)$, decreases in seawater $\mathrm{pH}$ (by $\sim 0.3-0.5$ units), shifts in carbon chemistry, sea level rise, and the increase in the strength and frequency of extreme weather events (GIBBARD et al., 2005; IPCC, 2014).

Global change is likely to have a profound impact on the physiology of a range of marine species across many phyla. However, warmer seawater temperatures and ocean acidification (OA) are expected to have a stronger negative effect on crustose coralline species, such as most rhodolith species, than on other macroalgal taxa (DONEY et al., 2009). Data from multiple mesocosm studies on the effect of OA and/or temperature rise on different species of macroalgae suggest that the magnitude of algal growth and calcification responses to OA seems to be species-specific (e.g. PRICE et al., 2011; JOHNSON et al., 2012; CAMPBELL et al., 2014). However, as a general rule, most calcareous algae seem to experience a reduction in biomineralization, while non-calcareous algae either show no effect or become more productive (DONEY et al., 2009; JOHNSON et al., 2012; KROEKER et al., 2012).

Calcified organisms can also act as buffers to OA, since they release $\mathrm{CO}_{3}{ }^{2-}$ ions that bind with free $\mathrm{H}^{+}$protons to form $\mathrm{HCO}_{3}^{-}$, thus neutralizing the acidification process (DONEY et al., 2009; SABINE; TANHUA, 2010; BASSO, 2012).
Model predictions estimate that in the future seawater $\mathrm{CO}_{2}$ concentration will increase by $192 \%$ and $\mathrm{HCO}_{3}{ }^{-}$will increase by $14 \%$ from de-calcification processes (ROLEDA et al., 2012). These changes are expected to cause negative effects on marine calcifiers, both animals and algae, due to their reduced ability to maintain and/or renew their calcareous skeleton (FABRY et al., 2008; JOKIEL et al., 2008; TYRRELL, 2008; HURD et al., 2009; RUSSELL et al., 2009; SEMESI et al., 2009; CORNWALL et al., 2012; JOHNSON et al., 2012). Despite the prediction that OA can compromise calcification, this process depends on the particularities of the physiology and mineralogy of the different taxonomic groups (RODOLFO-METALPA et al., 2009).

As regards the two main crystallographic forms of biological carbonates, aragonite is twice as soluble as pure calcite, while calcite with high $\mathrm{Mg}$ concentrations $(8-12 \%)$ is more soluble than aragonite (MORSE et al., 2006). Changes in the chemistry of seawater or increased temperatures can change the $\mathrm{Mg}$ content in the calcification process, altering the solubility of these crystals and eventually enhancing the sensitivity of calcifiers to OA (AGEGIAN, 1985; see review BASSO, 2012). However, it has been shown that coralline algae are able to form dolomite (NASH et al., 2012; DIAZ-PULIDO et al., 2014), a feature that has been associated with organisms living in high-energy environments (NASH et al., 2013). This mineral, formed within the cell wall, provides potential stability to calcareous algae, as inferred from the geological record. In fact, a recent study has shown that coralline algae exposed to $\mathrm{OA}$ and conditions of increasing warmth increased their dolomite concentration by $200 \%$ (DIAZ-PULIDO et al., 2014). Dolomite-rich coralline red algae have 6-10 times lower rates of dissolution than those precipitating predominantly $\mathrm{Mg}$-calcite (NASH et al., 2013). This property must be responsible for its abundance during periods of high $\mathrm{CO}_{2}$ concentration in our geological past and represents an important aspect that should be taken into consideration when considering experiments about OA.

For many photosynthetic marine organisms, changes in $\mathrm{CO}_{2}$ availability may either have no effect or may alter their metabolism in either positive or negative ways (see review $\mathrm{KOCH}$ et al., 2013). For example, species whether without or with inefficient carbon concentration mechanisms are usually carbon limited. For these organisms, higher $\mathrm{pCO}_{2}$ increases the affinity of RUBISCO for $\mathrm{CO}_{2}$, with a consequent increase in their photosynthetic rates (see 
review $\mathrm{KOCH}$ et al., 2013). In the case of coralline algae, they that are considered to be one of the groups of calcifying taxa with the highest susceptibility to $\mathrm{OA}$, as they accrete high-Mg calcite, the most soluble form of $\mathrm{CaCO}_{3}$. (BOROWITZKA, 1982; MORSE et al., 2006). The $\mathrm{CaCO}_{3}$ deposition in this algal group occurs extracellularly within the cell wall (see review in BOROWTZKA, 1982), representing up to $80-90 \%$ of their biomass (BILAN; USOV, 2001).

Most studies about the OA effect on coralline algae report negative responses in growth and calcification (see Figure 6A; e.g. KUFFNER et al., 2008; SEMESI et al., 2009; NOISETTE et al., 2013; JOHNSON et al., 2014), but also in photosynthesis (e.g. ANTHONY et al., 2008; JOHNSON; CARPENTER, 2012; COMEAU et al., 2012; JOHNSON et al., 2014; KATO et al., 2014; TAIT, 2014), cell wall thickness (RAGAZZOLA et al., 2012; MCCOY; RAGAZZOLA, 2014b), reproduction (CUMANI et al., 2010), recruitment (KUFFNER et al., 2008), and survivorship (DIAZPULIDO et al., 2012). These strong negative OA effects on coralline algae have been shown to alter the competitive interactions between different species of these coralline algae (MCCOY; PFISTER, 2014a), between coralline algae and non-calcified algae (JOKIEL et al., 2008; KUFFNER et al., 2008; PORZIO et al., 2011; HOFMANN et al., 2012; KROEKER et al., 2013a,b), and also between coralline algae and grazer (MCCOY; PFISTER, 2014a). PORZIO et al. (2011) demonstrated a loss of $25 \%$ of coralline algae diversity in environments that are naturally acidified by submerged vents of $\mathrm{CO}_{2}$ off the Italian coast. These changes in the phytobenthic communities in acidified environments reinforce the hypothesis that different ecophysiological susceptibilities of different taxonomic groups will result in profound changes in the physiognomy of these benthic environments in the coming decades.

Most studies related to global climate change effects on coralline algae have focused so far on their response to OA, while only a few have also included other environmental factors (see Figure 6B), such as temperature (e.g. JOHNSON; CARPENTER, 2012; MARTIN et al., 2013; NOISETTE et al., 2013; COMEAU et al., 2014) and light conditions (GAO; ZHENG, 2010; COMEAU et al., 2014), or local factors, such as nutrient concentration (RUSSELL et al., 2009; STENGEL et al., 2014).
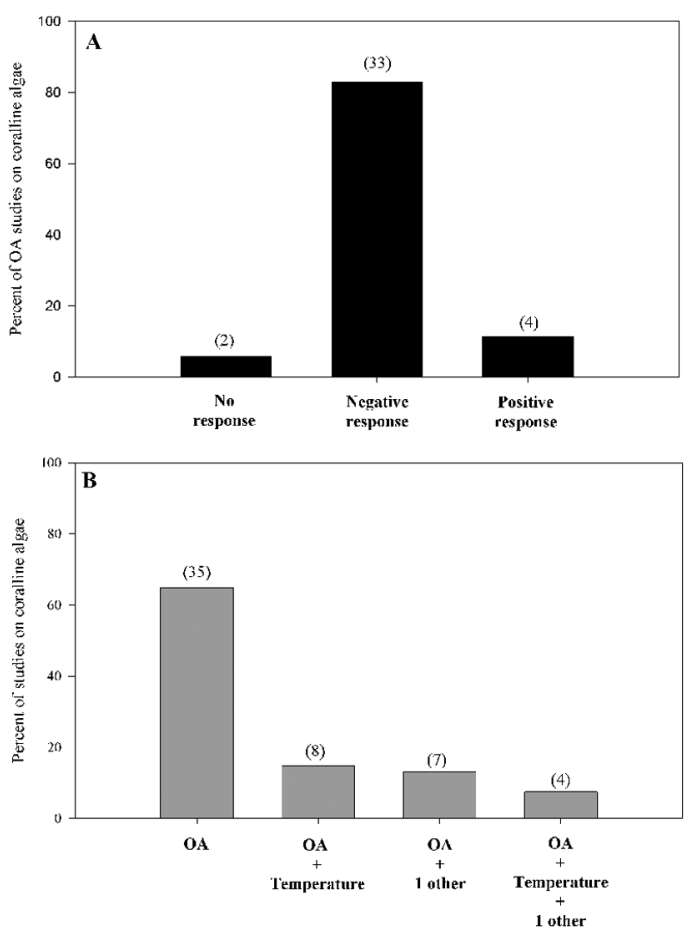

Figure 6. (A) Type of response of coralline algae (growth/ calcification) reported in ocean acidification studies $(\mathrm{n}=31)$, and (B) classification of experimental marine climate change studies on coralline algae ( $\mathrm{n}=56$ studies) according to the climate variable tested (OA- ocean acidification, Temp-temperature)

Besides a variety of studies investigating the OA response in coralline algae, only a few studies have been performed on the effect of the increase in seawater temperature and possible synergistic effects of ocean warming and acidification (see Figure 6B).

Generally, ocean warming is expected to affect algal community structure, seeing that temperature is an important general driver of the algal life cycle and consequently, of their phenology and distribution (RICHARDSON, 2008). All these changes can have a decisive impact on the changes in the distribution of populations, expanding the edges of the tropical population to higher latitudes, or excluding populations of colder waters (low temperature dependent) from their current subtropical or warm temperate environments, pushing them beyond these edges.

Studies combining OA and ocean warming scenarios have shown that there can be synergistic effects between both factors. For example, in Porolithon onkodes, the increase in $\mathrm{CO}_{2}$ causes high mortality and necrosis only when under high temperatures $\left(>28^{\circ} \mathrm{C}\right.$, DIAZ-PULIDO et al., 2012). In other experiments with the encrusting 
alga Lithophyllum cabiochiae from the Mediterranean, an additive effect of temperature was observed, resulting in higher mortality, necrosis and dissolution of the calcareous skeleton at high temperatures (MARTIN; GATTUSO, 2009). Thus both seawater $\mathrm{pH}$ and temperature, whether alone or in combination, will most likely change the physiognomy of rhodolith beds in the near future (see Figure7).

\section{$\mathrm{CO}_{2}$ Dissolved in Seawater}

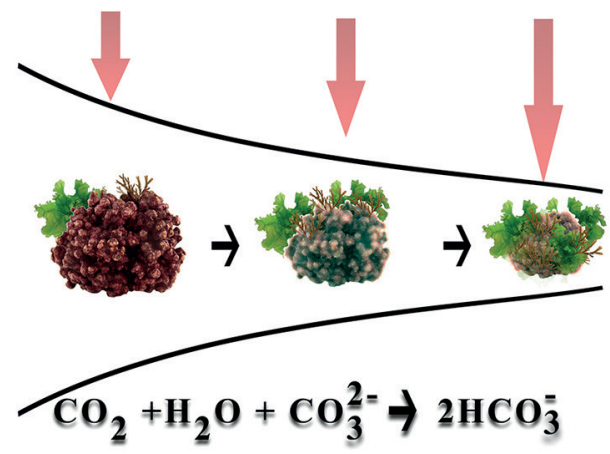

Temperature

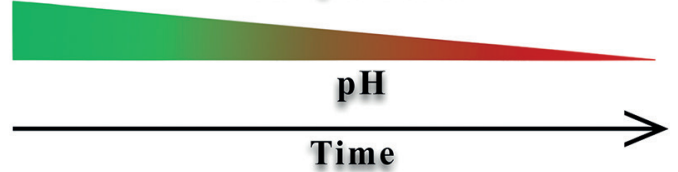

Figure 7. Schematic representation of rhodolith bed physiognomy impacted by warmer and more acidified waters in the future oceans, as predicted by the IPPC (2014).

Much of the effort that has addressed the impacts of climate change on the biology of marine primary producers remains limited and has dealt with aspects related to two initial treatment factors, acidification and temperature (WERNBERG et al., 2012). However, these factors have been occurring concomitantly, with other factors related to various processes associated with further changes in climate and other sources of stress. Thus, the significant future increase in rainfall (FAXNELD et al., 2010) as predicted to occur in south-central South America (IPCC, 2014) should act in parallel to the first two factors, changing environmental conditions, especially in coastal regions (see SCHERNER et al., 2012).

In addition to the future changes in temperature and the $\mathrm{pH}$ of seawater, there are other co-occurring drivers of environmental change, such as enhanced river run-off/ sedimentation due to an increase in rainfall (IPCC, 2014). Thus, larger volumes of sediments will be transported to the continental shelf. Sedimentation can influence the survival and growth of rhodoliths. WILSON et al. (2004) showed that rhodoliths when buried under gravel suffered less severe effects than those buried under fine sediment. They related the differences between sedimentation effects to the movement of water around the thalli, which also restricts gas exchange. Mud-rich sediment with high concentrations of sulphide was quite harmful to rhodoliths and associated biota. Also, rhodolith beds can be affected indirectly by discharges of drill cuttings from oil and gas activities (DAVIES et al., 2007). These activities on the Brazilian shelf adjacent to the beds result in a fine sediment cover of the algae that can cause reductions in their net primary production up to $50-70 \%$ (RIUL et al., 2008; FIGUEIREDO et al., 2015). This reduction in primary production severely impacts rhodolith-forming algae, and has high potential to compromise the establishment of associated diversity.

A greater amount of rainfall increases the flux of nutrients from urban and rural environments into the ocean, fertilizing coastal areas (VIAROLI et al., 2005; FAXNELD et al., 2010). Moreover, the growth of the human population and the increasing use of coastal areas represent the main sources of nutrient enrichment in marine environments, especially from sewage discharges (HALPERN et al., 2008; TEICHBERG et al., 2010; LUO et al., 2012). An increase of sewage-derived nutrients in the coastal marine environment changes the structure of phytobenthic communities in urbanized areas (MARTINS et al., 2012, SCHERNER et al., 2012).

An increase in the concentrations of dissolved nutrients in rhodolith beds constitutes an extremely important threat to this ecosystem (WILSON et al., 2004). Inorganic nitrogen and phosphate are the two most important nutrients for macroalgal growth and are consequently what promotes excessive blooms in macroalgal biomass (VIAROLI et al., 2005; TEICHBERG et al., 2010). Macroalgal blooms can produce conspicuous shifts in the marine benthic communities (SCHENER et al., 2012). Thus, nitrogen and phosphorus are considered limiting nutrients in many marine ecosystems (ZEHR; KUDELA, 2011). Opportunistic species, such as Ulva spp., are highly favoured in terms of growth with increasing quantities of nitrogen in the form of nitrate and ammonium (LUO et al., 2012). RUSSELL et al. (2009) observed that filamentous turfs are highly favoured by the 
increase in nutrients. On the other hand, perennial species, such as Sargassum stenophyllum, are negatively affected by increases in nutrient concentration, as evidenced by a decrease in photosynthesis with increasing concentrations of ammonium (SCHERNER et al., 2012). However, in the same study, in Ulva lactuca, the increase in ammonium concentrations produced an increase in photosynthetic activity. Thus, nitrogen pollution affects algae differently, depending on the species and eventual interaction with other factors (MARTINS et al., 2012). GRALL and HALL-SPENCER (2003) have described the effects of agricultural pollution, urban sewage, and industrial waste on rhodolith beds in France. The main consequences were similar to those described for other types of sedimentary habitats and environments, such as an increase in siltation and a higher abundance and biomass of opportunistic species, which replace sensitive ones. A radical change in rhodolith-associated biota together with a reduction in species diversity and area of live rhodolith cover was observed. The authors mentioned two rhodolith beds that have been killed in the Bay of Brest, both of which were situated directly under sewage outflows.

Of all the factors that determine the structure of a rhodolith bed, the regime of waves and currents is the most significant (ATABAY, 1998). Rhodolith beds require high energy hydrodynamic regimes. The fragmentation of coralline algae deposits culminates with the formation of new individuals, storms being the main driving force for the formation of rhodolith beds. However, rhodolith beds do not develop if the water dynamic is excessively strong to the point where it causes unsustainable loss rates of thalli, or transports individuals outside suitable habitats. Likewise, weak currents and wave action cause stabilization and overgrowth by larger algal species or burial by fine sediments, leading to rhodolith death (MARRACK, 1999; FOSTER et al., 2013). Although poorly documented (FREIWALD, 1995), these phenomena are keys to understanding the structure of the rhodolith bed community and its dynamics. Water transparency is also a fundamental factor in the distribution of rhodolith beds (CANALS; BALLESTEROS, 1996).

As documented by AMADO-FILHO et al. (2010), the diversity and abundance of the associated community of a shallow-water rhodolith bed is inversely related to the frequency and intensity of extreme events or cold fronts, which are more frequent and intense especially during the winter (PASCELLI et al., 2013). These phenomena may increase water motion and the frequency of the rolling of rhodoliths, eroding the surface and reducing the diversity and biomass of associated soft-bodied algae. It should also be borne in mind that these phenomena reduce light availability near the bottom, theoretically reducing the potential primary production of these formations.

\section{INTERACTIONS BETWEEN GLOBAL AND LOCAL}

\section{STRESSORS}

Besides the anthropogenic impacts that increase nutrient concentrations in coastal regions (MARTINS et al., 2012), global-change related scenarios that predict more intense and frequent rainfall will also result in more river run-off. Hence, larger volumes of land-derived pollutants will be transported to the continental shelf, severely impacting coastal marine communities. This drainage can reduce the $\mathrm{pH}$ and enhance the $\mathrm{CO}_{2}$ concentration even further, especially in anthropogenically influenced estuaries, aggravating the global impacts (NORIEGA et al., 2012). Thus, drainage basins and associated estuaries represent important regions for evaluating interactions between local and global stressors (HOWARTH et al., 1995; CANALS; BALLESTEROS, 1996), including variations in rainfall patterns.

There are different ways in which global factors, such as temperature and acidification, can interact with local factors, such as nutrients: (1) isolated: the effect of each factor is not influenced by the effects produced by other factors studied independently; (2) additive: factors have a joint effect on the study object that is equal to the sum of the effects caused by each factor when tested in isolation; (3) synergy: the factors have a joint effect on the study object that is greater than the simple sum of the effects caused by each factor when acting in isolation; and (4) antagonistic: the factors have a negative interaction, one neutralizing the other. Most studies have focused on one factor at a time, few have addressed two factors simultaneously and rarely have three or more been tested together to assess the existence of potential multiple levels of interaction (Figure 6). It is true that experimental designs with three or more factors are difficult to implement because the number of necessary replicates increases exponentially and interpretation of results can become too complex. An example of a synergistic interaction has been given by RUSSELL et al. (2009), who detected an interaction between the effects of high $\mathrm{pCO}_{2}$ and nutrients on photosynthesis and algal cover parameters, compromising the performance of calcareous algae and encouraging the growth of turf species. Thus, local stressors, as well 
as climate change factors - have to be considered in the evaluation of likely future scenarios.

\section{CONSIDERATIONS FOR FUTURE RESEARCH}

Although important and abundant throughout the Brazilian coast, rhodolith beds are still poorly understood in many aspects. For example, recent molecular results (SISSINI et al., 2014; VIEIRA-PINTO et al., 2014) have reinforced the need for molecular information to clarify taxonomy and distribution patterns of key rhodolith bed-forming species. This is important in the context of conservation strategies, as without basic information about the distribution of the genetic diversity and population genetic connectivity of keystone, foundation and main engineering marine species along the Brazilian coast, conservation and management strategies may be compromised.

Another aspect that needs attention is the threats that global change and its possible interactions with local stressors represents for rhodolith beds. These threats can have numerous consequences for these ecosystems but, unfortunately, in Brazil studies investigating the impact of global change and/or local stressors are still lacking (KERR et al., 2016).

This demands networking within the Brazilian scientific community, in order to coordinate, for example, collective efforts to perform baseline characterization of these formations in Brazil. This characterization on a large scale will provide us with a better understanding of the factors that determine different patterns of diversity and abundance. This pioneering survey will also allow the selection of key areas for the implementation of a program for long-term monitoring. It will provide us with vital information for the creation and improvement of models that will enhance our ability to predict the distribution of these beds and their associated fauna and flora in the coming decades.

In order to provide evidence of the expected consequences of global change and possible interaction with local stressors for the marine environment, within a reasonable timeline (i.e. 5-10 years), we also need to prioritize where research efforts have to be placed. The three topics agreed upon by the authors, which should be given greatest priority are: (1) understanding how OA will interact with other anthropogenic and climatic stressors, (2) understanding whether species may adapt or become acclimatized to future OA conditions and how this will affect species interactions and ecosystem stability, and (3) monitoring and modelling temporal, spatial and habitat variability in carbonate chemistry in order to more accurately predict future changes on the regional and local scale. Whilst these topics are seen as particular priorities, in answering questions regarding the expected consequences of OA, many of the topics we have listed are interlinked, providing the background and context for other research areas. This represents a difficult task, requiring multistressor experiments with complex experimental designs that will require increased collaboration and joint funding initiatives to allow the manpower, expertise and funding to successfully carry them out. This will be vital, if we are to develop the most appropriate strategies for the mitigation or remediation of or even the adaptation to future scenarios related to global climate change.

\section{ACKNOWLEDGMENTS}

Financial support was provided by the Conselho Nacional de Desenvolvimento Científico e Tecnológico (CNPq 306917/2009-2 for PA Horta), INCT-RedeClima, Rebentos, Coral Vivo Project, Fundação de Amparo à Pesquisa do Estado de São Paulo (FAPESP-BIOTA), Coordenação de Aperfeiçoamento de Pessoal de Nível Superior (CAPES/PNPD02828/09-0 and CAPES/PNADB 2338000071/2010-61 for PA Horta). Fundação de Amparo à Pesquisa e Inovação do Estado de Santa Catarina (FAPES)

\section{REFERENCES}

ADEY, W. H.; TOWNSEND, R. A.; BOYKINS, W. T. The crustose coralline algae (Rhodophyta: Corallinaceae) of the Hawaiian Islands. Washington: Smithsonian Institution Press, 1982.

ADEY, W. H.; STENECK, R. S. Thermogeography over time creates biogeographic regions: a temperature/space/timeintegrated model and an abundance-weighted test for benthic marine algae. J. Phycol., v. 37, n. 5, p. 677-698, 2001.

AGEGIAN, C. R. The biochemical ecology of Porolithon gardineri (Foslie). 1985. 178 f. (PhD dissertation). Honolulu: University of Hawaii, 1985.

AMADO-FILHO, G. M.; MANEVELDT, G.; MANSO, R. C. C.; MARINS-ROSA, B. V.; PACHECO, M. R.; GUIMARÃES, S. M. P. B. Structure of rhodolith beds from 4 to 55 meters deep along the southern coast of Espírito Santo State, Brazil. Cienc. Mar., v. 33, n. 4, p. 399-410, 2007.

AMADO-FILHO, G. M.; MANEVELDT, G.; PEREIRA FILHO, G. H.; MANSO, R. C.; BAHIA, R. G.; BARRETO, M. B. B.; GUIMARÃES, S. M. P. B. Seaweed diversity associated with a Brazilian tropical rhodolith bed. Cienc. Mar., v. 36, n. 4, p. 371-391, 2010.

AMADO-FILHO, G. M; PEREIRA-FILHO, G. H. Rhodolith beds in Brazil: a new potential habitat for marine bioprospection. Rev. Bras. Farmacogn., v. 22, n. 4, p. 782-788, 2012. 
AMADO-FILHO, G. M.; MOURA, R. L.; BASTOS, A. C.; SALGADO, L. T.; SUMIDA, P. Y.; GUTH, A. Z.; FRANCINI-FILHO, R. B.; PEREIRA-FILHO, G. H.; ABRANTES, D. P.; BRASILEIRO, P. S.; BAHIA, R. G.; LEAL, R. N.; KAUFMAN, L.; KLEYPAS, J. A.; FARINA, M.; THOMPSON, F. L. Rhodolith Beds Are Major $\mathrm{CaCo}_{3}$ bio-factories in the tropical South West Atlantic. PLoS ONE, v. 7, n. 4, p. e35171, 2012a.

AMADO-FILHO, G. M.; PEREIRA-FILHO, G. H.; BAHIA, R. G.; ABRANTES, D. P.; VERAS, P. C.; MATHEUS, Z. Occurence and distribution of rhodolith beds on the Fernando de Noronha Archipelago of Brazil. Aquat. Bot., v. 101, p. 4145, 2012b.

ANTHONY, K. R. N.; KLINE, D. I.; DIAZ-PULIDO, G.; DOVE, S.; HOEGH-GULDBERG, O. Ocean acidification causes bleaching and productivity loss in coral reef builders. Proc. Natl. Acad. Sci. U S A, v. 105, n. 45, p. 17442-17446, 2008.

ATABEY, N. Facies characteristics and geographic distribution of rhodoliths and maerls (red algae) in Southern Shelf of the sea of Marmara. Mineral Res. Expl. Bull., v. 120, p. 55-61, 1998.

BAHIA, R. G.; ABRANTES, D.; BRASILEIRO, P. S.; PEREIRA FILHO, G. H.; AMADO FILHO, G. Rhodolith bed structure along a depth gradient on the northern coast of Bahia state, Brazil. Braz. J. Oceanogr., v. 58, n. 4, p. 323-337, 2010.

BAHIA, R. G.; RIOSMENA-RODRIGUEZ, R.; MANEVELDT, G. W.; AMADO-FILHO, G. M. First report of Sporolithon ptychoides (Sporolithales, Corallinophycidae, Rhodophyta) for the Atlantic Ocean. Phycol. Res., v. 59, n. 1, p. 64-69, 2011.

BAHIA, R. G.; AMADO-FILHO, G. M.; MANEVELDT, G. W.; ADEY, W. H.; JOHNSON, G.; MARINS, B. V.; LONGO, L. L. Sporolithon tenue sp. nov. (Sporolithales, Corallinophycidae, Rhodophyta): A new rhodolith-forming species from the tropical southwestern Atlantic. Phycol. Res., v. 62 , n. 1 , p. $44-54,2014 \mathrm{a}$.

BAHIA, R. G.; AMADO-FILHO, G. M.; MANEVELDT, G. W. Sporolithon molle (Heydrich) Heydrich (Sporolithales, Corallinophycidae, Rhodophyta): an addition to the Atlantic flora found on a remote oceanic island. Cryptogam. Algol., v. 35 , n. 1, p. 7-14, 2014b.

BARBERA, C.; BORDEHORE, C.; BORG, J. A.; GLÉMAREC, M.; GRALL, J.; HALL-SPENCER, J. M.; DE LA HUZ, C. H.; LANFRANCO, E.; LASTRA, M.; MOORE, P. G.; MORA, J.; PITA, M. E.; RAMOS-ESPLÁ, A. A.; RIZZO, M.; SÁNCHEZ-MATA, A.; SEVA, A.; SCHEMBRI, P. J.; VALLE, C. Conservation and management of northeast Atlantic and Mediterranean maerl beds. Aquat. Conserv. Mar. Freshw. Ecosyst., v. 13, p. 65-76, 2003.

BARRETO, C. C. Heterogeneidade espacial do habitat e diversidade específica: implicações ecológicas e métodos de mensuração. Oecol. Bras., v. 84, p. 158-163, 1999.

BASSO, D. Carbonate production by calcareous red algae and global change. Biodiversitas, v. 34, n. 1, p. 13-33, 2012.

BERLANDI, R. M.; FIGUEIREDO, M. A. O.; PAIVA, P. C. Rhodolith morphology and the diversity of polychaetes off the southeastern Brazilian coast. J. Coatal Res., v. 28, p. 280287, 2012.

BIOMAERL team. Conservation and management of Atlantic and Mediterranean Maerl beds. Aquatic. Conserv, v. 13, p. 65-76, 2001.
BILAN, M. I.; USOV, A. I. Polysaccharides of calcareous algae and their effect on the calcification process. Russ. J. Bioorganic Chem., v. 27, n. 1, p. 2-16, 2001.

BLAKE, C.; MAGGS, C. A. Comparative growth rates and internal banding periodicity of maerl species (Corallinales, Rhodophyta) from northern Europe. Phycologia, v. 42, p. 606-612, 2003.

BORGES, V. P.; BASTOS, E.; BATISTA, M. B.; BOUZON, Z.; LHULLIER, C.; SCHIMIDT, E. C.; SISSINI, M. N.; HORTA, P. A. The genus Melobesia (Corallinales, Rhodophyta) from subtropical South Atlantic, with addition of M. rosanoffi (Foslie) Lemoine. Phytotaxa, v. 190, n. 1, p. 268-276, 2014.

BOROWITZKA, M. A. Mechanisms in algal calcification. Prog. Phycol. Res., v. 1, p.137-177, 1982.

BOSELLINI, A.; GINSBURG, R. N. Form and internal structure of recent algal nodules (Rhodolites) from Bermuda. J. Geol., v. 79, p. 669-682, 1971.

BOSENCE, D. W. J. The occurrence and ecology of recent rhodoliths - a review. Heidelberg: Springer Verlag, 1983. p. 225-242.

BOUZON, J. L.; FREIRE, A. S. The fauna of Brachyura and Anomura (Decapoda; Crustacea) in the Arvoredo Marine Biological Reserve Southern Brazilian Coast. Braz. J. Biol., v. 67, n. 2, p. 321-325, 2007.

BRASILEIRO, P. S.; PEREIRA-FILHO, G. H.; BAHIA, R. G.; ABRANTES, D. P.; GUIMMARÃES, S. M. P. B.; MOURA R. L.; FRANCINI-FILHO, R. B.; BASTOS, A. C.; AMADOFILHO, G. M. Macroalgal composition and community structure of the largest rhodolith beds in the world. Mar. Biodivers., p. 1-14, 2015.

BRIDGE, T. C. L., DONE, T. J.; BEAMAN, R. J.; FRIEDMAN, A.; WILLIAMS, S. B.; PIZARRO, O.; WEBSTER, J. M. Topography, substratum and benthic macrofaunal relationships on a tropical mesophotic shelf margin, central Great Barrier Reef, Australia. Coral Reefs, v. 30, n. 1, p. 143-153, 2011.

BRODIE, J.; ZUCCARELLO, G. C. Systematics of the species rich algae: red algal classification, phylogeny and speciation. In: HODKINSON, T. R. (Ed.). Reconstructing the Tree of Life: Taxonomy and Systematics of Species Rich Taxa. Boca Ratón: CRC/Taylor and Francis, 2007. p. 317-330.

BROOM, J. E. S.; HART, D. R.; FARR, T. J.; NELSON, W. A.; NEIL, K. F.; HARVEY, A. S.; WOELKERLING, W. J. Utility of psbA and nSSU for phylogenetic reconstruction in the Corallinales based on New Zealand taxa. Mol. Phylogenet. Evol., v. 46, n. 3, p. 958-973, 2008.

CANALS, M.; BALLESTEROS, E. Production of carbonate particles by phytobenthic communities on the MallorcaMenorca shelf, northwestern Mediterranean Sea. Deep Sea Res., v. 44, p. 611-629, 1997.

CAMPBELL, J. E.; CRAFT, J. D.; MUEHLLEHNER, N.; LANGDON, C.; PAUL, V. J. Responses of calcifying algae (Halimeda spp.) to ocean acidification: implications for herbivores. Mar. Ecol. Prog. Ser., v. 514, p. 43-56, 2014.

COMEAU, S.; CARPENTER, R. C.; EDMUNDS, P. J. Coral reef calcifiers buffer their response to ocean acidification using both bicarbonate and carbonate. Proc. Biol. Sci., v. 280, n. 1753, p. 20122374, 2012.

COMEAU, S.; CARPENTER, R. C.; EDMUNDS, P. J. Effects of irradiance on the response of the coral Acropora pulchra and the calcifying alga Hydrolithon reinboldii to temperature elevation and ocean acidification. J. Exp. Mar. Biol. Ecol., v. 453, p. 2835,2014 
CORNWALL, C.; HEPBURN, C.; PRITCHARD, D.; CURRIE, K.; MCGRAW, C.; HUNTER, K.; HURD, C. Carbon-use strategies in macroalgae: differential responses to lowered $\mathrm{pH}$ and implications for ocean acidification. J. Phycol., v. 48, n. 1, p. 137-144, 2012.

COSTA, I. O.; HORTA, P. A.; BERGSTROM, E. R.; NUNES, M. C. Taxonomic study of crustose coralline algae of the northeastern Brazilian coast. Phytotaxa, v. 190, n. 1, p. 130161,2014

CRESPO, T. M.; BAHIA, R. G.; MANEVELDT, G. W.; AMADO-FILHO, G. M. Floristic composition of crustose coralline algae from St. Peter and St. Paul Archipelago, a summit of the Mid-Atlantic Ridge. Phytotaxa, v. 190, n. 1, p. 17-37, 2014.

CUMANI, F.; BRADASSI, F.; DI PASCOLI, A.; BRESSAN, G. Marine acidification effects on reproduction and growth rates of Corallinaceae spores (Rhodophyta). Rapp. Comm. Int. Mer Médit., v. 39, p. 735, 2010.

DAVIES, A. J.; ROBERTS, J. M.; HALL-SPENCER, J. Preserving deep-sea natural heritage: Emerging issues in offshore conservation and management. Conserv. Physiol., v. 138, n. 3/4, p. 299-312, 2007.

DIAS, G. T. M. Granulados bioclásticos: algas calcárias. Rev. Bras. Geof., v. 18, n. 3, p. 307-318, 2000.

DIAS, G. T. M; VILLAÇA, R. C. Coralline algae depositional environments on the Brazilian central southeastern shelf. J. Coastal Res., v. 28, n. 1, p. 270-279, 2012.

DIAZ-PULIDO, G.; ANTHONY, K.; KLINE, D.; DOVE, S.; HOEGH-GULDBERG, O. Interactions between ocean acidification and warming on the mortality and dissolution of coralline algae. J. Phycol., v. 48, n. 1, p. 32-39, 2012.

DIAZ-PULIDO, G.; NASH, M. C.; ANTHONY, K. R. N.; BENDER, D.; OPDYKE, B. N.; REYES-NIVIA, C.; TROITZSCH, U. Greenhouse conditions induce mineralogical changes and dolomite accumulation in coralline algae on tropical reefs. Nat. Commun., v. 5, p. 3310-3318, 2014.

DICKIE, G. Enumeration of algae collected at Fernando de Noronha by H. M. Moseley, N.A., naturalist to H.M.S. “Challenger”. J. Linn. Soc. (Bot.)., v. 14, p. 363-365, 1874.

DICKIE, G. Enumeration of Algæ from Bahia, collected by H. N. Moseley, M.A., Naturalist to H.M.S. 'Challenger' (Sept. 25th, 1873 J. Linn. Soc. (Bot.)., v. 14, n. 77, p. 377, 1875.

DONEY, S.; FABRY, V.; FEELY, R.; KLEYPAS, J. Ocean Acidification: The Other $\mathrm{CO}_{2}$ Problem. Ann. Rev. Mar. Sci., v. 1, p. 169-192, 2009.

FABRY, V.; SEIBEL, B.; FEELY, R.; ORR, J. Impacts of ocean acidification on marine fauna and ecosystem processes. J. Mar. Sci., v. 65, n. 3, p. 414-432, 2008.

FARIAS, J. N.; RIOSMENA-RODRIGUEZ, R.; BOUZON, Z.; OLIVEIRA, E. C.; HORTA, P. A. Lithothamnion superpositum (Corallinales; Rhodophyta): First description for the Western Atlantic or rediscovery of a species? Phycol. Res., v. 58, p. 210-216, 2010.

FAXNELD, S.; JÖRGENSEN, T.; TEDENGREN, M. Effects of elevated water temperature, reduced salinity and nutrient enrichment on the metabolism of the coral Turbinaria mesenterina. Coast. Shelf Sci., v. 88, n. 4, p. 482-487, 2010.

FIGUEIREDO, M. A.; NORTON, T. A.; KAIN, J. M. Settlement and survival of epiphytes on two intertidal crustose coralline algae. J. Exp. Mar. Biol. Ecol., v. 23, p. 247-260, 1997.
FIGUEIREDO, M. A.; MENEZES, K. S.; PAIVA, E. M. C.; PAIVA, P. C.; VENTURA, C. R. R. Evaluación experimental de rodolitos como sustratos vivos para la infauna em el Banco de Abrolhos, Brasil. Cienc. Mar., v. 33, n. 4, p. 427-440, 2007.

FIGUEIREDO, M. A.; COUTINHO, R.; VILLAS-BÔAS, A. B.; TÂMEGA, F. T. S.; MARIATH, R. Deep-water rhodolith productivity and growth in the southwestern Atlantic. J. Appl. Phycol., v. 24, n. 3, p. 487-493, 2012.

FIGUEIREDO, M. A.; EIDE, I.; REYNIER, M.; VILLAS-BOAS, A. B.; TÂMEGA, F. T. S.; FERREIRA, C. G.; NILSSEN, I.; COUTINHO, R.; JOHNSON, S. The effect of sediment mimicking drill cuttings on deep water rhodoliths in a flowthrough system: Experimental work and modeling. Mar. Pollut. Bull., v. 95, n. 1, p. 81-88, 2015.

FOSTER, M. S. Rhodoliths: between rocks and soft places. J. Phycol., v. 37, p. 659-667, 2001.

FOSTER, M. S.; AMADO-FILHO, G. M.; KAMENOS, N. A.; RIOSMENA-RODRÍGUEZ, R; STELLER, D. L. Rhodoliths and Rhodolith Beds. In: LANG, M. A.; MARINELLI, R. L.; ROBERTS, S. J.; TAYLOR, P. R. (Eds.). Research and Discoveries: The Revolution of Science through Scuba. Washington: Smithsonian Institution Scholarly Press, 2013. p. 143-155.

FREIWALD, A. Sedimentological and biological aspects in the formation of branched rhodoliths in northern Norway. Beitr. Paläeont., v. 20, p. 7-19, 1995.

GAO, K.; ZHENG, Y. Combined effects of ocean acidification and solar UV radiation on photosynthesis, growth, pigmentation and calcification of the coralline alga Corallina sessilis (Rhodophyta). Glob. Change Biol., v. 16, p. 2388-2398, 2010.

GHERARDI, D. F. M.; BOSENCE, D. W. J. Composition and community structure of the coralline algal reefs from Atol das Rocas, South Atlantic, Brazil. Coral Reefs, v. 19, n. 3, p. 205219, 2001.

GHERARDI, D. F. M. Community structure and carbonate production of a temperate rhodolith bank from Arvoredo Island, Southern Brazil. Braz. J. Oceanogr., v. 52, n. 3/4, p. 207-224, 2004.

GIBBARD, S.; CALDEIRA, K.; BALA, G.; PHILIPS, T. J.; WICKETT, M. Climate effects of global land cover change. Geophys. Res. Lett., v. 32, n. 23, p. L23705, 2005.

GONDIM, A. I.; DIAS, T. L. P.; DUARTE, R. C. S.; RIUL, P.; LACOUTH, P.; CHRISTOFFERSEN, M. L. Filling a knowledge gap on the biodiversity of Rhodolith-associated Echinodermata from northeastern Brazil. Trop. Conserv. Sci., v. 7, n. 1, p. 87-99, 2014.

GRALL, J.; HALL-SPENCER, J. M. Problems facing maerl conservation in Brittany. Aquat. Conserv., v. 12, p. 55-64, 2003.

GUIMARÃES, S. M. B. P.; AMADO FILHO, G. M. 2008. A community of gelatinous rhodophytes in the sublittoral of southern Espírito Santo State, Brazil. Bot. Mar. 51: 378-387.

GUIRY, M. D.; GUIRY, G. M. AlgaeBase. World-wide electronic publication, National University of Ireland, Galway. Available: $<$ http://www.algaebase.org $>$. 2015.

HALFAR, J.; RIEGL, B. From coral framework to rhodolith bed: sedimentary footprint of the $1982 / 1983$ ENSO in the Galápagos. Coral Reefs, v. 32, n. 4, p. 985, 2013.

HALPERN, B. S.; WALBRIDGE, S.; SELKOE, K. A.; KAPPEL, C. V.; MICHELI, F.; D'AGROSA, C.; BRUNO, J. F.; CASEY, K. S.; EBERT, C.; FOX, H. E.; FUJITA, R.; HEINEMANN, D.; LENIHAN, H. S.; MADIN, E.; 
PERRY, M.; SELIG, E.; SPALDING, M.; STENECK, R.; WATSON, R. A Global Map of Human Impact on Marine Ecosystems. Science, v. 319, n. 5865, p. 948-952, 2008.

HENRIQUES, M. C.; COUTINHO, L. M.; RIOSMENARODRÍGUEZ, R.; BARROS-BARRETO, M. B.; KHADER, S.; FIGUEIREDO, M. A. O. Three deep water species of Sporolithon (Sporolithales, Rhodophyta) from the Brazilian continental shelf, with the description of Sporolithon elevatum sp. nov. Phytotaxa, v. 190, p. 320-330, 2014a.

HENRIQUES, M. C.; RIOSMENA-RODRÍGUEZ, R.; COUTINHO, L. M.; FIGUEIREDO, M. A. O. Lithophylloideae and Mastophoroideae (Corallinales, Rhodophyta) from the Brazilian continental shelf. Phytotaxa, v. 190, n. 1, p. 112-129, 2014b.

HINDERSTEIN, L. M.; MARR, J. C. A.; MARTINEZ, F. A.; DOWGIAllo, M. J.; PUGLISE, K. A.; PYLE, R. L.; ZAWADA, D. G.; APPELDOORN, R. Theme section on mesophotic coral ecosystems: Characterization, ecology, and management. Coral Reefs, v. 29, p. 247-251, 2010.

HOFMANN, L. C.; STRAUB, S.; BISCHOF, K. Competition between calcifying and noncalcifying temperate marine macroalgae under elevated $\mathrm{CO}_{2}$ levels. Mar. Ecol. Prog. Ser., v. 464 , p. $89-105,2012$ b.

HORTA, P. A. Bases para a identificação das coralináceas não articuladas do litoral brasileiro: uma síntese do conhecimento. Biotemas, v. 15, p. 7-44, 2002.

HORTA, P. A.; AMANCIO, C. E.; COIMBRA, C.; OLIVEIRA, E. C. Considerações sobre a distribuição e origem da flora de macroalgas marinhas brasileiras. Hoehnea, v. 28, p. 243-265, 2001.

HOWARTH, R. W.; JENSEN, H. S.; MARINO, R.; POSTMA, $\mathrm{H}$. Transport and processing of $\mathrm{P}$ in Near-shore and Oceanic Waters. In: THIESSEN, H. (Ed.). Phosphorus in the Global Environment. Chichester: John Wiley \& Sons Ltd; 1995. 476 p.

HURD, C.; HEPBURN, C.; CURRIE, K.; RAVEN, J.; HUNTER, K. Testing the effects of ocean acidification on algal metabolism considerations for experimental designs. J. Phycol., v. 45, n. 6, p. 1236-1251, 2009.

IPCC: Climate Change: Impacts, Adaptation, and Vulnerability. Part A: Global and Sectorial Aspects. Contribution of Working Group II to the Fifth Assessment Report of the Intergovernment Panel on Climate Change. In: FIELD, C. B.; BARROS, V. R.; DOKKEN, D. J.; EBI, K. L.; ESTRADA, Y. O.; GENOVA, R. C.; GIRMA, B.; KISSEL, E. S.; LEVY, A. N.; MACCRACKEN, S.; MASTRANDEA, P. R.; WHITE, L. L. (Eds.). Cambridge: Cambridge University Press; 2014. $1132 \mathrm{p}$.

JOHNSON, M. D.; CARPENTER, R. C. Ocean acidification and warming decrease calcification in the crustose coralline alga Hydrolithon onkodes and increase susceptibility to grazing. J. Exp. Mar. Biol. Ecol., v. 435, p. 94-101, 2012.

JOHNSON, V.; RUSSELL, B.; FABRICIUS, K.; BROWNLEE, C.; HALL-SPENCER, M. Temperate and tropical brown macroalgae thrive, despite decalcification, along natural $\mathrm{CO}_{2}$ gradients. Glob. Change Biol., v. 18, n. 9, p. 2792-2803, 2012.

JOHNSON, M. D.; MORIARTY, V. W.; CARPENTER, R. C. Acclimatization of the crustose coralline alga Porolithon onkodes to variable $p \mathrm{CO}_{2}$. PLoS ONE, v. 9, n. 2, p. e87678, 2014.
JOKIEL, P. L.; RODGERS, K. S.; KUFFNER, I. B.; ANDERSON, A. J.; COX, E. F.; MACKENZIE, F. T. Ocean acidification and calcifying reef organisms: a mesocosm investigation. Coral Reefs, v. 27, n. 3, p. 473-483, 2008.

KATO, A.; HIKAMI, M.; KUMAGAI, N. H.; SUZUKI, A.; NOJIRI, Y.; SAKAI, K. Negative effects of ocean acidification on two crustose coralline species using genetically homogeneous samples. Mar. Environ. Res., v. 94, p. 1-6, 2014.

KEMPF, M. Notes on the benthic bionomy of the N-NE Brazilian shelf. Mar. Biol., v. 5, p. 213-224, 1970.

KERR, R., DA CUNHA, L. C., KIKUCHI, R. K., HORTA, P. A., ITO, R. G., MÜLLER, M. N., ... \& PINHEIRO, B. R. (2015). The western south Atlantic Ocean in a high- $\mathrm{CO}_{2}$ world: current measurement capabilities and perspectives. Environmental management, 1-13.

KOCH M, BOWES G, ROSS C, ZHANG XH (2013) Climate change and ocean acidification effects on seagrasses and marine macroalgae. Global Change Biol 19:103-132

KROEKER, K. J.; MICHELI, F.; GAMBI, M. C. Ocean acidification causes ecosystem shifts via altered competitive interactions. Nat. Clim. Chang., v. 3, p. 156-159, 2012.

KROEKER, K. J.; KORDAS, R. L.; CRIM, R.; HENDRIKS, I.; RAMAJO, L.; SINGH, G. S.; DUARTE, C. M.; GATTUSO, J. P. Impacts of ocean acidification on marine organisms: quantifying sensitivities and interaction with warming. Glob. Change Biol., v. 19, n. 6, p. 1884-1896, 2013.

KUFFNER, I. B.; ANDERSSON, A. J.; JOKIEL, P. L.; RODGERS, K. S.; MACKENZIE, F. T. Decreased abundance of crustose coralline algae due to ocean acidification. Nat. Geosci., v. 1, p. 114-117, 2008.

LAVRADO, H. P. Caracterização do ambiente e da comunidade bentônica. Capítulo 1. In: LAVRADO, H. P.; IGNÁCIO, B. L. (Eds.). Biodiversidade bentônica da região central da Zona Econômica Exclusiva Brasileira. Rio de Janeiro: Série Livros do Museu Nacional, Museu Nacional, 2006. p. 1966.

LITTLER, M. M. The crustose Corallinaceae. Oceanogr. Mar. Biol., v. 10, p. 311-347, 1972.

LITTLER, M. M.; LITTLER, D. S.; BLAIR, S. M.; NORRIS, J. N. Deep-water plant communities from an uncharted seamount off San Salvador Island, Bahamas: distribution, abundance, and primary productivity. Deep Sea Res., v. 33, n. 7, p. 881-892, 1986 .

LUO, M.; LIU, F.; XU, Z. Growth and nutrient uptake capacity of two co-occurring species, Ulva prolifera and Ulva linza. Aquat. Bot., v. 100, p. 18-24, 2012.

MARINS, B. V.; AMADO-FILHO, G. M.; BARRETO, M. B. B.; LONGO, L. L. Taxonomy of the southwestern Atlantic endemic kelp: Laminaria abyssalis and Laminaria brasiliensis (Phaeophyceae, Laminariales) are not different species. Phycol. Res., v. 60, p. 51-60, 2012.

MARTIN, S.; GATTUSO, J. P. Response of Mediterranean coralline algae to ocean acidification and elevated temperature. Glob. Change Biol., v. 15, p. 2089-2100, 2009.

MARTIN, S.; COHU, S.; VIGNOT, C.; ZIMMERMAN, G.; GATTUSO, J. P. One-year experiment on the physiological response of the Mediterranean crustose coralline alga, Lithophyllum cabiochae, to elevated $p \mathrm{CO}_{2}$ and temperature. Ecol. Evol., v. 3, n. 3, p. 676-693, 2013. 
MARTINS, C. D. L.; ARANTES, N.; FAVERI, C.; BATISTA, M. B.; OLIVEIRA, E. C.; PAGLIOSA, P. R.; FONSECA, A. L.; NUNES, J. M. C.; CHOW, F.; PEREIRA, S. B.; HORTA, P. A. The impact of coastal urbanization on the structure of phytobenthic communities in southern Brazil. Mar. Pollut. Bull., v. 64, n. 4, p.772-778, 2012.

MARRACK, E. C. The relationship between water motion and living rhodolith beds in the southwestern Gulf of California, Mexico. Palaios, v. 14, p. 159-171, 1999.

MCCOY, S. J.; PFISTER, C. A. Historical comparisons reveal altered competitive interactions in a guild of crustose coralline algae. Ecol. Lett., v. 17, n. 4, p. 475-483, 2014a.

MCCOY, S. J.; RAGAZZOLA, F. Skeletal trade-offs in coralline algae in response to ocean acidification. Nat. Clim. Chang., v. 4, p. 719-723, 2014b.

MEIRELLES, P. M.; AMADO-FILHO, G. M.; PEREIRAFILHO, G. H.; PINHEIRO, H. T.; MOURA, R. L.; JOEUX, J. C.; MAZZEI, E. F.; BASTOS, A. C.; EDWARDS, R. A.; DINSDALE, E.; PARANHOS, R.; SANTOS, E. O.; IIDA, T.; GOTOH, K.; NAKAMURA, S.; SAWABE, T.; REZENDE, C. E.; GADELHA Jr, L. M. R.; FRANCINI-FILHO, R. B.; THOMPSON, C.; THOMPSON, F. L. Baseline Assessment of Mesophotic Reefs of the Vitória-Trindade Seamount Chain Based on Water Quality, Microbial Diversity, Benthic Cover and Fish Biomass Data. PLoS ONE, v. 10, n. 6, p. e130084, 2015.

MILlimANN, J. D.; AMARAL, C. A. B. Economic potential of Brazilian continental margin sediments. An. Congr. Bras. Geogr., v. 28, p. 335-344, 1974.

METRI, R.; ROCHA, R. M. Bancos de algas calcárias, um ecossistema rico a ser preservado. Nat. Cons., v. 6, p. 8-17, 2008.

MORSE, J. W.; ANDERSSON, A. J.; MACKENZIE, F. T. Initial responses of carbonate-rich shelf sediments to rising atmospheric $p \mathrm{CO}_{2}$ and "ocean acidification": Role of high Mg-calcites. Geochim. Cosmochim. Acta, v. 70, n. 23, p. 5814-5830, 2006.

MOURA, R. L.; SECCHIN, N. A.; AMADO-FILHO, G. M.; FRANCINI-FILHO, R. B.; FREITAS, M. O.; MINTEVERA, C. V.; TEIXEIRA, J. B.; THOMPSON, F. L.; DUTRA, G. F.; SUMIDA, P. Y. G.; GUTH, A. Z.; LOPES, R. M.; BASTOS, A. C. Spatial patterns of benthic megahabitats and conservation planning in the Abrolhos Bank. Cont. Shelf Res., v. 70, p. 109-117, 2013

NASH, M. C.; TROITZSCH, U.; OPDYKE, B. N.; TRAFFORD, J. M.; RUSSELL, B. D.; KLINE, D. I. First discovery of dolomite and magnesite in living coralline algae and its geobiological implications. Biogeosciences, v. 8, n. 11, p. 3331-3340, 2012.

NASH, M. C.; OPDYKE, B. N.; TROITZSCH, U.; RUSSELL, B. D.; ADEY, W. H.; KATO, A.; DIAZ-PULIDO, G.; BRENT, C.; GARDNER, M.; PRICHARD, J.; KLINE, D. I. Dolomiterich coralline algae in reefs resist dissolution in acidified conditions. Nat. Clim. Chang., v. 3, p. 268-272, 2013.

NELSON, W. A. Calcified macroalgae - critical to coastal ecosystems and vulnerable to change: a review. Mar. Freshwat. Res., v. 60, n. 8, p. 787-801, 2009.

NOISETTE, F., EGILSDOTTIR, H., DAVOULT, D., \& MARTIN, S. (2013). Physiological responses of three temperate coralline algae from contrasting habitats to near-future ocean acidification. J. Exp. Mar. Biol. Ecol., 448, 179-187.
NORIEGA, R.; SCHLACHER, T. A.; SMEUNINX, B. Reductions in Ghost Crab Populations Reflect Urbanization of Beaches and Dunes. J. Coast. Res., v. 28, n. 1, p. 123-131, 2012.

NUNES, J. M. C.; GUIMARÃES, S. M. P. B.; DONANGELO, A., FARIAS, J.; HORTA, P. A. Aspectos taxonômicos de três espécies de coralináceas não geniculadas do litoral do estado da Bahia, Brasil. Rodriguésia, v. 59, n. 1, p. 75-86, 2008.

OLIVEIRA, E. C. Is there a relation among the global warming, the missing carbon and the calcareous algae? An. Acad. Bras. Cienc., v. 68, p. 18-21, 1996.

OLIVEIRA, E. C. Letters. Science, v. 277, p. 1991, 1997.

PASCELLI, C.; RIUL，P.; RIOSMENA-RODRIGUEZ，R.; SCHERNER, F.; NUNES, M. HALL-SPENCER, J. M.; OLIVEIRA, E. C.; HORTA, P. A. Seasonal and depth-driven changes in rhodolith bed structure and associated macroalgae off Arvoredo island (southeastern Brazil). Aquat. Bot., v. 111, p. 62-65, 2013.

PEÑA,V.,BÁRBARA,I.,GRALL,J.,MAGGS,C.A.\&HALLSPENCER, J.M. (2014a). The diversity of seaweeds on maerl in the NE Atlantic. Marine Biodiversity, 44: 533-551.

PEREIRA-FILHO, G. H.; AMADO-FILHO, G. M.; GUIMARÃES, S. M. P. B.; MOURA, R. L.; SUMIDA, P. Y. G; ABRANTES, D. P.; BAHIA, R.; GÜTH, A. Z.; JORGE, R. R.; FRANCINI-FILHO, R. B. Reef Fish and Benthic assemblages of the Trindade and Martin Vaz island group, Southwestern Atlantic. Braz. J. Oceanogr., v. 59, n. 3, p. 201-212, 2011.

PEREIRA-FILHO, G. H.; AMADO-FILHO, G. M.; MOURA, R. L.; BASTOS, A. C.; GUIMARÃES, S. M. P. B.; SALGADO, L. T.; FRANCINI-FILHO, R. B.; BAHIA, R. G.;ABRANTES, D. P.; GUTH, A. Z.; BRASILEIRO, P. S. Extensive Rhodolith Beds Cover the Summits of Southwestern Atlantic Ocean Seamounts. J. Coastal. Res., v. 28, p. 261-269, 2012.

PEREIRA-FILHO, G. H.; FRANCINI-FILHO, R. B.; PIEROZZIJR, I.; PINHEIRO, H. T.; BASTOS, A. C.; MOURA, R. L.; COEIXAS, F.; MATHEUS, Z.; BAHIA, R. G.; AMADOFILHO, G. M. Sponges and fish facilitate succession from rhodolith beds to reefs. Bull. Mar. Sci., v. 91, n. 1, p. 45-46, 2015.

PORZIO, L.; BUIA, M. C.; HALL-SPENCER, J. M. Effects of ocean acidification on macroalgal communities. J. Exp. Mar. Biol. Ecol., v. 400, n. 1/3, p. 278-287, 2011.

PRICE, N. N.; HAMILTON, S. L.; TOOTELL, J. S.; SMITH, J. E. Species-specific consequences of ocean acidification for the calcareous tropical green algae Halimeda. Mar. Ecol. Prog. Ser., v. 440, p. 67-78, 2011.

RAGAZZOLA, F.; FOSTER, L. C.; FORM, A.; ANDERSON, P. L.; HANSTEEN, T. H.; FIETZKE, J. Ocean acidification weakens the structural integrity of coralline algae. Glob. Change Biol., v. 18, p. 2804-2812, 2012.

RICHARDSON, A. In hot water: Zooplankton and climate change. J. Mar. Sci., v. 65, p. 279-295, 2008.

RIUL, P.; TARGINO, C. H.; FARIAS, J. N.; VISSCHER, P. T.; HORTA, P. A. Decrease in Lithothamnion sp. (Rhodophyta) primary production due to the deposition of a thin sediment layer. J. Mar. Biol. Assoc. U. K., v. 88, p. 17-19, 2008.

RIUL, P.; LACOUTH, P.; PAGLIOSA, P. R.; CHRISTOFFERSEN, M. L.; HORTA, P. A. Rhodolith beds at the easternmost extreme of South America: Community structure of an endangered environment. Aquat. Bot., v. 90, p. 315-320, 2009. 
ROCHA, R. M.; MORENO, T. R.; METRI, R. Ascídias da Reserva Biológica Marinha do Arvoredo, SC. Rev. Bras. Zool., v. 22, p. 461-476, 2005.

RODOLFO-METALPA, R.; MARTIN, S.; FERRIER-PAGÈS, C.; GATTUSO, J. P. Response of the temperate coral Cladocora caespitosa to mid- and long-term exposure to $\mathrm{pCO}_{2}$ and temperature levels projected for the year 2100AD. Biogeosciences 7: 289-300. Biogeosci. Discuss., v. 6, n. 4, p. 7103-7131, 2009.

ROLEDA, M.; BOYD, P.; HURD, C. Before ocean acidification: calcifier chemistry lessons. J. Phycol., v. 48, p. 840-843, 2012.

RUSSELL, B. D.; THOMPSON, J. A.; FALKENBERG, L. J.; CONNELL, S. D. Synergistic effects of climate change and local stressors: $\mathrm{CO}_{2}$ and nutrient-driven change in subtidal rocky habitats. Glob. Change Biol., v. 15, n. 9, p. 2153-2162, 2009.

SABINE, C.; TANHUA, T. Estimation of Anthropogenic $\mathrm{CO}_{2}$ Inventories in the Ocean. Annu. Rev. Mar Sci., v. 2, p. 175-198, 2010.

SANTOS, A. S.; RIUL, P.; BRASIL, A. C. S.; CHRISTOFFERSEN, M. L. Encrusting Sabellariidae (Annelida: Polychaeta) in rhodolith beds, with description of a new species of Sabellaria from the Brazilian coast. J. Mar. Biol. Ass. U. K., v. 91, p. 425-438, 2011.

SCHERNER, F.; RIUL, P.; BASTOS, E.; BOUZON, Z. L.; PAGLIOSA, P. R.; BLANKENSTEYN, A.; OLIVEIRA, E. C.; HORTA, P. A. Herbivory in a rhodolith bed: a structuring factor? Pan. Am. J. Aquat. Sci., v. 5, p. 358-366, 2010.

SCHERNER, F.; BONOMI, J.; HORTA, P. Photosynthetic response of two seaweed species along an urban pollution gradient: evidence of selection of pollution-tolerant species. Mar. Pollut. Bull., v. 64, p. 2380-2390, 2012.

SEMESI, S.; KANGWE, J.; BJORK, M. Alterations in seawater $\mathrm{pH}$ and $\mathrm{CO}_{2}$ affect calcification and photosynthesis in the tropical coralline alga, Hydrolithon sp. (Rhodophyta). Estuar. Coast. Shelf Sci., v. 84, p. 337-341, 2009.

SISSINI, M. N.; OLIVEIRA, M. C.; GABRIELSON, P. W.; ROBINSON, N. M.; YURI, B. O.; RIOSMENA-RODRÍGUEZ, R.; HORTA, P. A. Mesophyllum erubescens (Corallinales, Rhodophyta) - so many species in one epithet. Phytotaxa, v. 190, p. 299-319, 2014.

STELLER, D. L.; RIOSMENA-RODRÍGUEZ, R.; FOSTER, M. S.; ROBERTS, C. A. Rhodolith bed diversity in the Gulf of California: the importance of rhodolith structure and consequences of disturbance. Aquatic. Conserv. Mar. Freshw. Ecosyst., v. 13, p. 5-20, 2003.

STENGEL, D. B.; CONDE-ÁlVAREZ, R.; CONNAN, S.; NITSCHKE, U.; ARENAS, F.; ABREU, H.; BARUFI, J. B.; CHOW, F.; ROBLEDO, D.; MALTA, E. J.; MATA, M.; KONOTCHICK, T.; NASSAR, C.; PÉREZ-RUZAFA, A.; LÓPEZ, D.; MARQUARDT, R.; VAZ-PINTO, F.; CELIS-PLÁ, P. S. M.; HERMOSO, M.; RUIZ, E.; ORDOÑEZ, G.; FLORES, P.; ZANOLLA, M.; BAÑARES-ESPAÑA, E.; ALTAMIRANO, M.; KORBEE, N.; BISCHOF, K.; FIGUEROA, F. L. Shortterm effects of $\mathrm{CO}_{2}$, nutrients and temperature on three marine macroalgae under solar radiation. Aquat. Biol., v. 22, p. 159-176, 2014.

TAIT, L. W. Impacts of natural and manipulated variations in temperature, $\mathrm{pH}$ and light on photosynthetic parameters of coralline-kelp assemblage. J. Exp. Mar. Biol. Ecol., v. 454, p. $1-8,2014$.

TEICHBERG, M.; FOX, S.; OLSEN, Y.; VALIELA, I.; MARTINETTOS, P.; IRIBARNES, O.; YURIKO-MUTO, E.; PETTI, M.; CORBISIER, T.; SOTO-JIMENEZ, M.; PAEZ-OSUNA, F.; CASTRO, P.; FREITAS, H.; ZITELLI,
A.; CARDINALETTTI, M.; TAGLIAPIETRAS, D. Eutrophication and macroalgal blooms in temperate and tropical coastal waters: nutrient enrichment experiments with Ulva spp. Glob. Change Biol., v. 16, p. 2624-2637, 2010.

TEICHERT, S.; WOELKERLING, W.; RÜGGEBERG, A.; WISSHAK, M.; PIEPENBURG, D.; MEYERHÖFER, M.; FORM, A.; BÜDENBENDER, J.; FREIWALD, A. Rhodoliths beds (Corallinales, Rhodophyta) and their physical and biological environment at $80^{\circ} 31^{\prime} \mathrm{N}$ in Nordkappbukta (Nordaustlandet, Svalbard Archipelago, Norway). Phycologia, v. 51, p. 371-390, 2012.

TESTA, V.; BOSENCE, D. W. J. Physical and biological controls on the formation of carbonate and siliciclastic bedforms on the northeast Brazilian shelf. Sedimentology, v. 46, p. 279-301, 1999.

TESTA, V. Crustose Corallines, macroalgae, herbivores and sediments: Complex interactions along productivity gradients. Proceedings of the 8th International Coral Reef Symposium, v. 1, p. 737-742, 1997.

TORRANO-SILVA, B. N.; RIOSMENA-RODRÍGUEZ, R.; OLIVEIRA, M. C. Systematic position of Paulsivella in the Lithophylloideae (Corallinaceae, Rhodophyta) confirmed by molecular data. Phytotaxa, v. 190, n. 1, p. 94-111, 2014.

TYRRELL, T. Calcium carbonate cycling in future oceans and its influence on future Climates. J. Plankton. Res., v. 30, n. 2, p. 141-156, 2008.

UNEP. Draft updated action plan on protecting the coralligenous and other calcareous bio-concretions in the Mediterranean Sea. Reports SPA/RAC Focal points meeting. Palermo, Italy: UNESO, 2007. 18 p.

UNEP. Draft action plan on protecting the coralligenous and other calcareous bio-concretions in the Mediterranean Sea. Reports SPA/RAC Focal points meeting for specially protected areas. Athens, Greece: UNESCO, 2015. 18 p.

VAN DER HEIJDEN, L. H.; KAMENOS, N. A. Reviews and syntheses: Calculating the global contribution of coralline algae to total carbon burial: Biogeosciences, v. 12, p. 6429-6441, 2015

VIAROLI, P.; BARTOLI, M.; AZZONI, R.; GIORDANI, G.; MUCCHINO, C.; NALDI, M.; NIZZOLI, D.; TAJÉ, L. Nutrient and iron limitation to Ulva blooms in a eutrophic coastal lagoon (Sacca di Goro, Italy). Hydrobiologia, v. 550 , p. $57-71,2005$.

VIEIRA-PINTO, T.; OLIVEIRA, M. C.; BOUZON, J.; SISSINI, M. N.; RICHARDS, J. L.; RIOSMENARODRÍGUEZ, R.; HORTA, P. A. Lithophyllum species from Brazilian coast: range extension of Lithophyllum margaritae and description of Lithophyllum atlanticum sp. nov. (Corallinales, Corallinophycidae, Rhodophyta). Phytotaxa, v. 190, p. 355-369, 2014.

VILLAS-BÔAS, A. B.; RIOSMENA-RODRIGUEZ, R.; AMADO-FILHO, G. M.; MANEVELDT, G.; FIGUEIREDO, M. A. Rhodolith-forming species of Lithophyllum (Corallinales; Rhodophyta) from Espírito Santo State, Brazil, including the description of $L$. depressum sp. nov. Phycologia, v. 48, p. 237-248, 2009.

VILLAS-BÔAS, A. B.; RIOSMENA-RODRÍGUEZ, R.; FIGUEIREDO, M. A. O. Community structure of rhodolith-forming beds on the central Brazilian continental shelf. Helgol. Mar. Res., v. 68, n. 1, p. 27-35, 2014 a. 
VILLAS-BÔAS, A. B.; TÂMEGA, F. T. S.; ANDRADE, M.; COUTINHO, R.; FIGUEIREDO, M. A. O. Experimental Effects of Sediment Burial and Light Attenuation on Two Coralline Algae of a Deep Water Rhodolith Bed in Rio de Janeiro, Brazil. Cryptogam. Algol., v. 35, n. 1, p. 67-76, 2014b.

WERNBERG, T.; SMALE, D.; THOMSEN, M. A decade of climate change experiments on marine organisms: procedures, patterns and problems. Glob. Change Biol., v. 18, p. 1491-1498, 2012.
WILsON, S.; BLAKE, C.; BERGES, J. A.; MAGGS, C. A. Environmental tolerances of free-living coralline algae (maërl): implications for European marine conservation. Biol. Conserv., v. 120, p. 279-289, 2004.

WOELKERLING, W. J. Growth-forms in Non-geniculate Coralline Red Algae (Corallinales, Rhodophyta). Aust. Syst. Bot., v. 6, p. 277-293, 1993.

ZEHR, J.; KUDELA, R. Nitrogen Cycle of the Open Ocean: From Genes to Ecosystems. Annu. Rev. Mar. Sci., v. 3, p. 197-225, 2011. 
